\title{
Potentiation of RNA polymerase II transcription by Gal4-VP16 during but not after DNA replication and chromatin assembly
}

\author{
Rohinton T. Kamakaka, Michael Bulger, and James T. Kadonaga ${ }^{1}$ \\ Department of Biology and Center for Molecular Genetics, University of California, San Diego, La Jolla, California \\ 92093-0347 USA
}

Purified, reconstituted chromatin templates containing regular, physiological nucleosome spacing were transcribed in vitro by RNA polymerase II along with the Gal4-VP16 activator. When Gal4-VP16 was prebound to DNA before reconstitution of either H1-deficient or H1-containing chromatin, the resulting templates were transcribed with a similar efficiency. Under such conditions, we observed long-range (1000 bp) activation of transcription in vitro with H1-containing chromatin, but not naked DNA templates. When Gal4-VP16 was added to preassembled chromatin, the H1-deficient chromatin was transcriptionally active, whereas the H1-containing chromatin, which possessed properties similar to native chromatin, was transcriptionally inert. We then mimicked DNA replication and chromatin assembly at a replication fork and found that Gal4-VP16 could potentiate transcription during, but not after, replication and assembly of histone H1-containing chromatin. These experiments provide biochemical data that support a DNA replication-dependent mechanism for reconfiguration of chromatin structure and activation of transcription by Gal4-VP16.

[Key Words: chromatin; histone H1; DNA replication; RNA polymerase II; Gal4-VP16; in vitro transcription]

Received May 13, 1993; revised version accepted July 14, 1993.

Many biological phenomena are dependent on the proper control of gene transcription, and the expression of each of the tens of thousands of genes in a higher eukaryote is governed by a complex program that specifies the procedural nature of every stage in the transcription process. As an early step in the understanding of gene activity, it has been useful to examine the underlying mechanisms of transcription. Studies of mRNA synthesis in eukaryotes have led to significant insight into basal transcription by RNA polymerase II (for reviews, see Saltzman and Weinmann 1989; Sawadogo and Sentenac 1990; Conaway and Conaway 1991; Roeder 1991; Pugh and Tjian 1992; Weis and Reinberg 1992; Zawel and Reinberg 1992, 1993; Drapkin et al. 1993), as well as the regulation of transcription by sequence-specific DNA-binding factors (for reviews, see Ptashne 1988; Johnson and McKnight 1989; Mitchell and Tjian 1989; Hahn 1993). It has also been important to consider the structure of the DNA template itself, that is, the relation between chromatin structure and gene activity. A significant body of data generated both in vivo and in vitro suggests that components of chromatin, such as nucleosomal cores

${ }^{1}$ Corresponding author. and histone $\mathrm{H1}$, can act as global repressors of transcription and that sequence-specific transcription factors can function both to counteract the chromatin-mediated repression ("antirepression") and to facilitate the inherent transcription process, such as the assembly of the transcription initiation complex (for reviews, see Weintraub 1985; van Holde 1989; Grunstein 1990; Svaren and Chalkley 1990; Kornberg and Lorch 1991; Simpson 1991; Felsenfeld 1992; Wolffe 1992; Adams and Workman 1993; Croston and Kadonaga 1993; Workman and Buchman 1993). Moreover, recent biochemical experiments suggest that packaging of DNA into chromatin is necessary for threshold phenomena and long-distance activation of transcription, such as the action of enhancers (Laybourn and Kadonaga 1992; Schild et al. 1993).

In the analysis of chromatin structure and gene regulation, it is important to investigate the mechanisms by which the repressed chromatin template can be rendered accessible to transcription factors to allow gene activation. For many genes, transcriptional activation may be dependent on DNA replication-mediated disruption of chromatin structure (Fig. 1A) (see, e.g., Weintraub 1979; Brown 1984; Solomon and Varshavsky 1987; Almouzni et al. 1990). In this model the transient perturbation of chromatin structure that occurs on DNA replication al- 
A

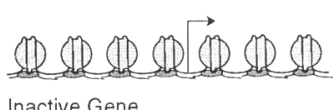

B

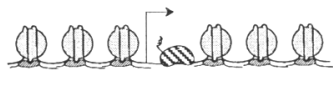

Pre-Activated Gene

C

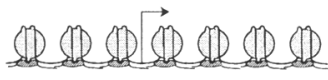

Inactive Gene

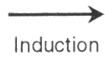

(1) Tran

Figure 1. Models for DNA replication and gene activation. $(A)$ Replication-dependent binding of transcription factors and reconfiguration of chromatin structure. $(B)$ Replication-independent activation of transcription from a preactivated gene. $(C)$ Replication-independent reconfiguration of chromatin structure and transcriptional activation.

lows the binding of promoter- and enhancer-binding factors that otherwise would not have had access to the DNA template. Alternatively, gene activation can occur in the absence of DNA replication (Fig. 1B,C). For example, in the uninduced Drosophila hsp 70 gene, RNA polymerase II is engaged transcriptionally but paused after the synthesis of a nascent RNA of $\sim 25$ nucleotides, and heat induction results in the binding of the heat shock factor and transcriptional elongation by the polymerase (Rougvie and Lis 1988). In this instance, replication-independent transcriptional activation occurs with a preactivated gene containing DNA-bound transcription factors (Fig. 1B). It also appears that reconfiguration of chromatin structure and transcriptional activation can occur in the absence of DNA replication (Fig. 1C). This mechanism for gene activation has been observed with the mouse mammary tumor virus long terminal repeat (LTR) promoter (Richard-Foy and Hager 1987) and the yeast $P H O 5$ gene (Schmid et al. 1992). The proportionate usage of replication-dependent or -independent mechanisms for chromatin reconfiguration and gene activation in vivo has yet to be determined but possibly may be related to the context and function of the individual genes.

In this study we describe a biochemical analysis of chromatin structure and transcription by RNA polymerase II. First, we achieved the reconstitution and purification of chromatin with physiological properties with regard to nucleosomal spacing and incorporation of histone $\mathrm{H} 1$, and we analyzed the transcriptional properties of the chromatin templates. We then examined the relation among DNA replication, chromatin assembly, and transcription factor-mediated potentiation of the DNA template by carrying out DNA replication and chromatin assembly reactions in situ in either the presence or

the absence of the Gal4-VP16 hybrid protein (Sadowski et al. 1988; Ptashne 1988; Chasman et al. 1989), which was used as a model of a simple transcriptional activator. The Gal4-VP16 activator was able to potentiate transcription during but not after replication/assembly of histone Hl-containing chromatin templates. These findings with H1-containing chromatin suggest that the presence of the Gal4-VP16 activator is not sufficient to mediate reconfiguration of chromatin structure and gene activation in the absence of DNA replication.

\section{Results and discussion}

Reconstitution and purification of chromatin with properties similar to those of native chromatin

The role of chromatin structure in the regulation of transcription is an important yet controversial issue that addresses the fundamental mechanisms by which genes are regulated. Studies performed in vivo have suggested that alterations in chromatin structure accompany gene activation, whereas biochemical experiments have revealed that promoter- and enhancer-binding factors can function to counteract chromatin-mediated repression. In the biochemical studies, however, it has been a legitimate point of concern whether or not the chromatin that has been reconstituted in vitro has functioned as an accurate model for the structure of chromatin in vivo.

Therefore, the initial goal of these studies was to assemble nucleosomal cores and histone $\mathrm{Hl}$ onto doublestranded plasmid DNA to yield chromatin with properties similar to those of native chromatin. Yet, although procedures have been described for the reconstitution of regularly spaced chromatin with extracts from Xenopus oocytes (see, e.g., Glikin et al. 1984; Rodríguez-Campos et al. 1989; Shimamura et al. 1989a,b/ or preblastoderm (0-100 min after fertilization) Drosophila embryos (Becker and Wu 1992), methodology did not exist that was easily scaled-up to the quantities that were necessary for our present and future studies. Thus, we devoted a significant effort toward the reconstitution of evenly spaced chromatin from extracts of Drosophila embryos collected from 0 to $6 \mathrm{hr}$ after fertilization. The design of this method for chromatin reconstitution was influenced initially by previous studies of chromatin and nuclei reconstitution (see, e.g., Newport 1987; Shimamura et al. 1989b; Ulitzur and Gruenbaum 1989; Berrios and Avilion 1990; Crevel and Cotterill 1991; Becker and Wu 1992). In contrast to the other procedures, however, the new Drosophila S-190 extract contains low levels of endogenous core histones and must be supplemented with exogenous core histones for chromatin assembly.

The crude, reconstituted chromatin was first analyzed by partial micrococcal nuclease digestion and supercoiling assays (Fig. 2). Partial digestion of the chromatin with micrococcal nuclease cleaves the linker DNA between the nucleosomal cores; and if the nucleosomes are regularly spaced, a ladder of DNA fragments that corresponds to oligonucleosomes is generated (Noll and Kornberg 1977). The Drosophila S-190 extract contained low 
A

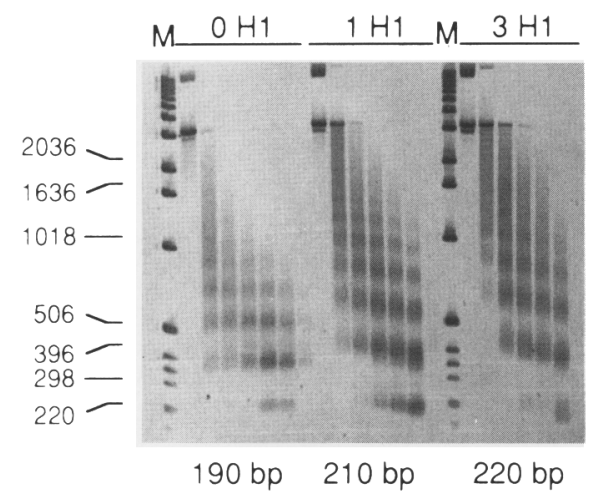

B

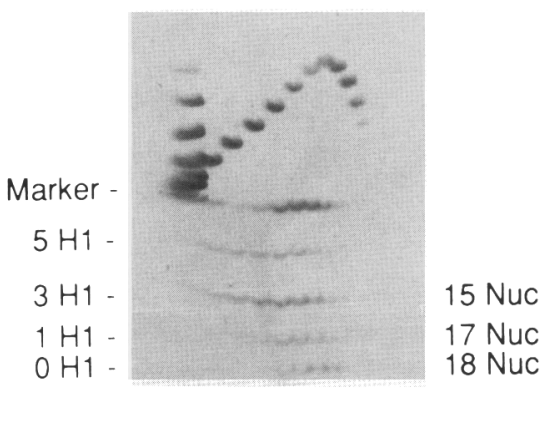

C

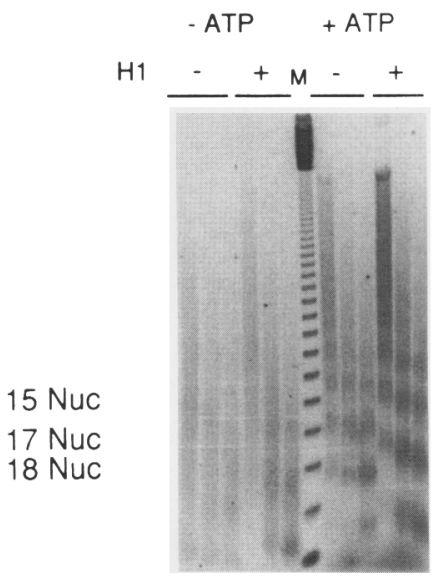

D

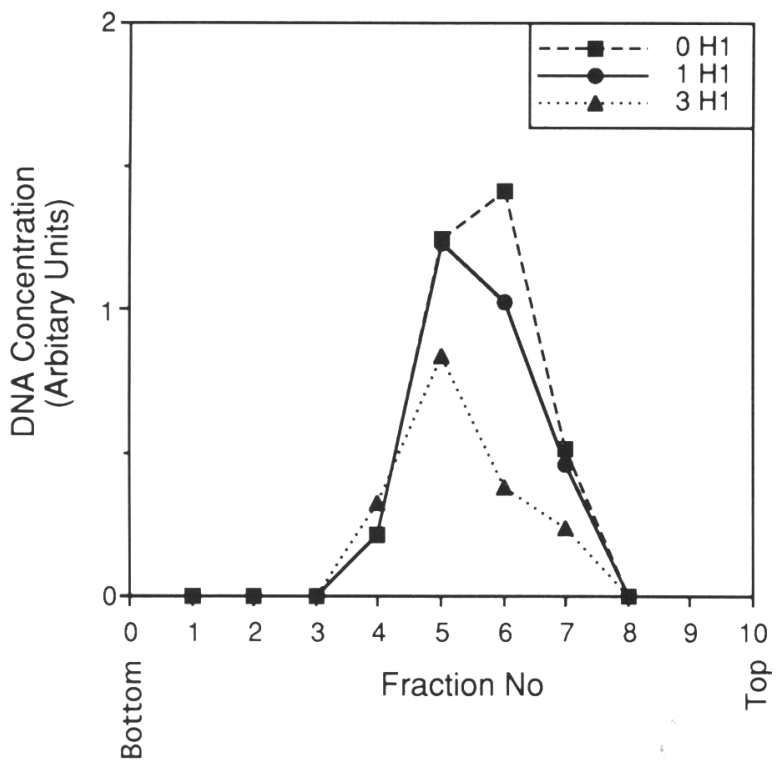

levels of histone $\mathrm{H} 1$, and the repeat length of the reconstituted chromatin increased from $\sim 190$ to $220 \mathrm{bp}$ as the amount of exogenous $\mathrm{Hl}$ added to the reactions was increased (Fig. 2A). This effect of $\mathrm{Hl}$ on the nucleosomal repeat length is similar to that observed previously with other reconstitution systems (Rodríguez-Campos et al. 1989; Becker and Wu 1992). The micrococcal ladder shown in Figure 2A, which represents an average experiment, has distinct bands that indicate regular spacing of the nucleosomal cores in the reconstituted chromatin. Moreover, it was necessary to include ATP in the reaction medium to generate the even nucleosomal spacing (Fig. 2C), as observed previously in the reconstitution of chromatin with extracts from Xenopus oocytes (Glikin et al. 1984).

The efficiency of nucleosome deposition with the
Figure 2. Reconstitution of chromatin with even nucleosomal spacing by using a Drosophila embryo extract. $(A)$ Incorporation of histone $\mathrm{Hl}$ affects the nucleosome repeat length but not the regularity of nucleosome spacing. Reconstitution reactions were carried out with varying amounts of exogenous histone $\mathrm{Hl}$ (zero, one, or three molecules per 200-bp DNA). The reconstituted chromatin was partially digested with micrococcal nuclease, and the resulting DNA fragments were analyzed by $1.5 \%$ agarose gel electrophoresis. (B) Two-dimensional topological assay. Chromatin was reconstituted with varying amounts of exogenous histone $\mathrm{Hl}$ (zero, one, three, or five molecules per 200 bp DNA), deproteinized, and then subjected to two-dimensional agarose gel electrophoresis. The average number of nucleosomes per plasmid (3249 bp) is indicated. $(C)$ ATP is required for even nucleosomal spacing. Chromatin was reconstituted in the presence or absence of ATP, as indicated, and then digested with micrococcal nuclease and analyzed by agarose gel electrophoresis. $(D)$ Sucrose gradient sedimentation analysis of reconstituted chromatin. Chromatin was reconstituted with varying amounts of exogenous histone $\mathrm{H} 1$ (zero, one, or three molecules per 200-bp DNA) and then subjected to sedimentation in a $30-50 \%$ sucrose gradient. The DNA profiles of the gradient fractions are shown.

Drosophila extract was examined by DNA supercoiling analysis (Fig. 2B). In the presence of topoisomerase I (which is in the S-190 extract), the deposition of one nucleosome on a circular DNA gives a change of -1 in the linking number (Germond et al. 1975; Simpson et al. 1985). Thus, the efficiency of nucleosome deposition was determined by the change in the linking number that had occurred with reconstitution of chromatin. The reconstituted chromatin was deproteinized, and the efficiency of nucleosome deposition was deduced from the change in DNA supercoiling that was measured by twodimensional agarose gel electrophoresis under conditions that allowed resolution of the individual topoisomers (Peck and Wang 1983; Shimamura et al. 1988; Laybourn and Kadonaga 1991). In the absence of $\mathrm{Hl}$, there was an average of 18 nucleosomes per 3249 -bp plasmid (1 
nucleosome per $181 \mathrm{bp}$. When the reactions were performed in the presence of one or three molecules of exogenous $\mathrm{H} 1$ per 200-bp DNA, there were an average of 17 and 15 nucleosomes per 3249-bp plasmid (1 nucleosome per 191 and $217 \mathrm{bp}$ ), respectively. These results correlate well with the repeat lengths observed in the micrococcal nuclease digestion assay (Fig. 2A) and further indicate that there was a high efficiency of nucleosome deposition.

Before analysis of the transcriptional properties of the reconstituted chromatin, we felt that it was essential to purify the chromatin to near homogeneity. In this manner, the interpretation of the effects of chromatin structure on transcription would be more straightforward because of the absence of free histones and other contaminating species. We therefore purified the reconstituted chromatin by sucrose gradient sedimentation (Fig. 2D). Consistent with the properties of native chromatin (Butler and Thomas 1980), the H1-containing chromatin sedimented slightly faster than the H1-deficient chromatin. In addition, the sucrose gradient sedimentation did not affect the regularity of the nucleosome spacing, as determined by micrococcal nuclease digestion analysis. The protein composition of the purified chromatin was analyzed by polyacrylamide-SDS gel electrophoresis (Fig. $3 \mathrm{~A})$, which revealed that the histones were the major proteins in the chromatin. Similarly, the plasmid DNA was the principal nucleic acid present in the purified chromatin. [In contrast to the behavior of the Xenopus oocyte S-150 extract (Shimamura and Worcel 1989), there was no detectable change in acetylation of histone H4 with chromatin reconstitution with the Drosophila
S-190, as determined by Triton-acid-urea gel electrophoresis.] Quantitative Western blot analysis with antibodies against either Drosophila histone $\mathrm{H} 1$ or Drosophila histones $\mathrm{H} 2 \mathrm{~A}$ and $\mathrm{H} 2 \mathrm{~B}$ revealed that the addition of 0,1 , or 3 molecules of exogenous $\mathrm{H} 1$ to the reconstitution reactions resulted in purified chromatin containing $0.2,0.8$, or 1.4 molecules of $\mathrm{H} 1$ per nucleosomal core, respectively. Thus, chromatin that was reconstituted with exogenously added $\mathrm{H} 1$ contained levels of $\mathrm{H} 1$ that were comparable with that observed with native chromatin (roughly one molecule of $\mathrm{Hl}$ per nucleosome; Bates and Thomas 1981).

The interaction between histone $\mathrm{Hl}$ and the nucleosomal cores was also investigated. First, native polyacrylamide gel electrophoresis of micrococcal nuclease digestion products of the reconstituted chromatin (Varshavsky et al. 1976; Nelson et al. 1979) revealed a species that comigrated with a native chromatosome from the H1-containing chromatin (Fig. 3B). In addition, extensive micrococcal nuclease digestion of the reconstituted chromatin generated DNA fragments of $146 \mathrm{bp}$ from the H1-deficient chromatin and of 166 bp from the H1-containing chromatin (Fig. 3C), which is identical to that observed with native chromatin (Simpson 1978; Allan et al. 1980). These results suggest that the histone $\mathrm{Hl}$ in the reconstituted chromatin is located at its physiological site on the nucleosomal pseudo-dyad.

Finally, we examined the reconstituted chromatin by electron microscopy (Fig. 3D). Electron micrographs of purified chromatin at low ionic strength revealed nucleosomes of even spacing throughout the plasmid molecule. There were no stretches of nucleosome-free DNA.
A

C

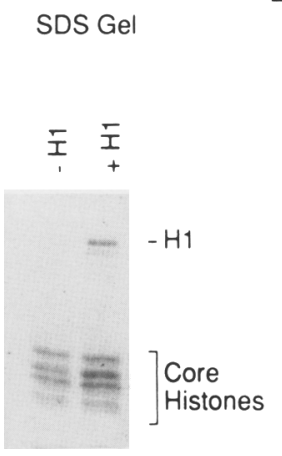

B

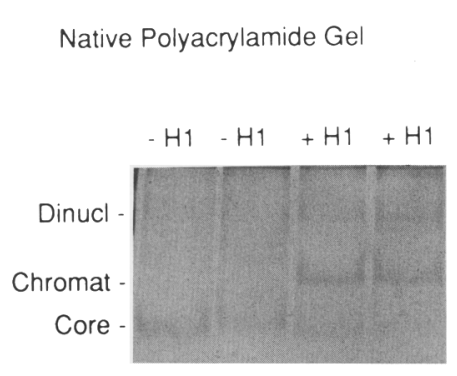

Agarose Gel

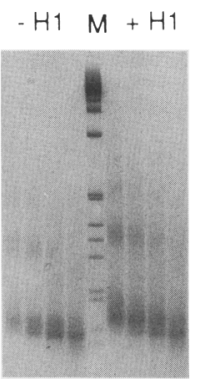

D
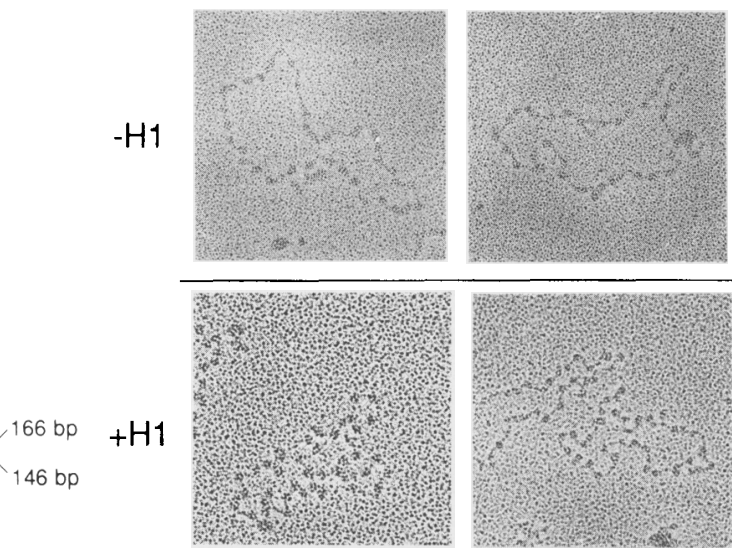

Figure 3. Purified, reconstituted chromatin possesses properties similar to those of native chromatin. Chromatin was reconstituted in the presence or absence of exogenous histone $\mathrm{H} 1$ and then purified by $30-50 \%$ sucrose gradient sedimentation. $(A)$ Analysis of the protein composition of the purified chromatin by $18 \%$ polyacrylamide-SDS gel electrophoresis and silver staining. The positions of the core histones and histone $\mathrm{Hl}$ are indicated. $(B)$ Examination of the incorporation of histone $\mathrm{H} 1$ by nucleoprotein gel electrophoresis. The purified, reconstituted chromatin was digested with micrococcal nuclease and then subjected to native $5 \%$ polyacrylamide gel electrophoresis. The $-\mathrm{Hl}$ and $+\mathrm{Hl}$ lanes are in duplicate. The positions of migration of core particles, chromatosomes, and dinucleosomes are indicated. $(C)$ Analysis of the length of the DNA fragments released with digestion of reconstituted chromatin with micrococcal nuclease. $(D)$ Electron micrographs of chromatin reconstituted in the presence or absence of exogenous histone $H 1$. 
In addition, the reconstituted H1-containing chromatin exhibited the characteristic zigzag appearance of native chromatin in which the linker DNA enters and exits from the same side of the nucleosomal core (see, e.g., Thoma et al. 1979). Moreover, when exogenous $\mathrm{Hl}$ is not included in the reconstitution reaction, the entry and exit sites of the linker DNA of the resulting chromatin appeared to be at opposite sides of the nucleosomal cores, which is similar to that observed with $\mathrm{Hl}$-depleted native chromatin (Thoma et al. 1979). Hence, on the basis of protein and nucleic acid composition, analyses of micrococcal nuclease digestion products, sucrose gradient sedimentation, and appearance in electron micrographs, we concluded that the chemical and physical properties of the purified, reconstituted Hl-containing chromatin were similar to those of native chromatin.

\section{Distinct transcriptional properties of $\mathrm{H} 1$-deficient and H1-containing chromatin}

The purified chromatin templates were then subjected to in vitro transcription analysis with a high efficiency transcription system derived from Drosophila embryos (Kamakaka et al. 1991) and the Gal4-VP16 hybrid protein as a model of a simple transcriptional activator (Ptashne 1988; Sadowski et al. 1988).

Initially, in these experiments, we examined the effect of adding the Gal4-VP16 activator to the DNA template either before or after reconstitution of $\mathrm{Hl}$-containing or H1-deficient chromatin. In this manner, we addressed two issues: (1) whether or not the Gal4-VP16 activator could counteract repression of transcription by preassembled chromatin (as depicted in Fig. 1C), which has been suggested by previous studies (Taylor et al. 1991; Lorch et al. 1992; Workman and Kingston 1992); and (2) whether or not the incorporation of histone $\mathrm{Hl}$ into the chromatin affects the transcriptional properties of the resulting templates. With regard to the latter point, it is important to note that native chromatin of higher eukaryotes contains about one molecule of $\mathrm{H1}$ per nucleosome (Bates and Thomas 1981); therefore, H1-containing chromatin is probably a better model for native chromatin than $\mathrm{H} 1$-deficient chromatin.

Chromatin was reconstituted onto double-stranded, circular $\mathrm{pG}_{5} \mathrm{E} 4 \mathrm{Kr}$ DNA in the presence or absence of exogenously added histone $\mathrm{Hl}$ and purified by sucrose gradient sedimentation before in vitro transcription analysis (Fig. 4A). The $\mathrm{pG}_{5} \mathrm{E} 4 \mathrm{Kr}$ template was derived from $\mathrm{pG}_{5} \mathrm{E} 4 \mathrm{~T}$ (Lin et al. 1988) and contains five Gal4binding sites $19 \mathrm{bp}$ upstream of the TATA box of the adenovirus E4 promoter. The Gal4-VP16 activator was (1) omitted from the reactions, (2) added before reconstitution, (3) added after purification, or (4) added both before reconstitution and after purification of the chromatin. The transcriptional analysis of the resulting templates revealed the following. First, in the absence of Gal4-VP16, there was a 15-fold repression of transcription with deposition of nucleosomal cores (Fig. 4A, lanes $8,14 \mid$ and an 86 -fold repression with reconstitution of H1-containing chromatin (Fig. 4A, lanes 12,14). When
Gal4-VP16 was prebound to the DNA template before chromatin reconstitution, it was able to counteract transcriptional repression to the same extent with either $\mathrm{H} 1$ deficient or $\mathrm{H} 1$-containing chromatin (Fig. 4A, lanes 1-6, and B). The magnitude of activation by Gal4-VP16 increased from 12-fold with naked DNA (Fig. 4A, lanes 13,14 ) to 77 -fold with the $\mathrm{H1}$-containing chromatin (Fig. $4 \mathrm{~A}$, lanes 6,12 , and B). This ability of Gal4-VP16 to relieve chromatin-mediated inhibition of transcription has been observed previously and is sometimes referred to as antirepression (Croston et al. 1991a; Laybourn and Kadonaga 1991; Workman et al. 1991).

There was, however, a sharp difference in the transcriptional properties of $\mathrm{Hl}$-containing versus $\mathrm{Hl}$-deficient chromatin templates when Gal4-VP16 was added after reconstitution and purification. When Gal4-VP16 was added to $\mathrm{H} 1$-deficient chromatin templates after reconstitution, it was able to counteract the chromatinmediated repression to the same extent that was observed with H1-deficient chromatin to which Gal4VP16 was prebound before reconstitution (Fig. 4A, lanes 2,7 , and B). In contrast, when Gal4-VP16 was added to H1-containing chromatin templates after reconstitution, the amount of transcription was significantly less than that observed with $\mathrm{Hl}$-containing templates to which Gal4-VP16 was prebound before reconstitution (Fig. 4A, lanes 6,11 ; Fig. 4B). Thus, it appears that Gal4-VP16 can function to counteract transcriptional repression by preassembled $\mathrm{Hl}$-deficient chromatin but not $\mathrm{Hl}$-containing chromatin.

To clarify the interpretation of these data, the following experiments were performed. First, we examined the effect of the presence of the Gal4-VP16 protein on chromatin reconstitution by micrococcal nuclease digestion analysis and found that the regularity of nucleosome spacing was unaffected by the activator protein (Fig. $4 \mathrm{C}$ ). Second, Western blot and DNase I footprinting experiments indicated that Gal4-VP16 added to the DNA before chromatin reconstitution remained bound to the templates after sucrose gradient purification (Fig. 4C). This finding was consistent with the observation that the addition of Gal4-VP16 to the chromatin templates after reconstitution and purification did not significantly increase the levels of transcription when Gal4-VP16 was prebound to the DNA before reconstitution (Fig. 4A, lanes $1-6$, and B). Third, transcriptional activation by Gal4-VP16 was dependent on the presence of Gal4-binding sites in the template DNA. Therefore, the transcriptional effects observed were attributable to Gal4-VP16 bound to its recognition sites upstream of the TATA box.

In addition, to complement the transcriptional analysis, we carried out nuclease accessibility studies with the reconstituted chromatin templates (Fig. 4D). Chromatin was reconstituted onto $\mathrm{pG}_{5} \mathrm{E} 4 \mathrm{Kr} \mathrm{DNA}$ and then purified by sucrose gradient sedimentation as described in the transcriptional studies (Fig. 4A,B), but the resulting templates were treated with a restriction endonuclease instead of basal transcription factors. In these experiments, we used the restriction enzyme $X b a I$, which digests 
$\mathrm{pG}_{5} \mathrm{E} 4 \mathrm{Kr}$ at a unique site located $6 \mathrm{bp}$ downstream of the Gal4-binding sites and $7 \mathrm{bp}$ upstream of the TATA box of the adenovirus E4 promoter. The H1-deficient chromatin was equally accessible to digestion by $\mathrm{XbaI}$ when Gal4-VP16 was (1) omitted from the reaction, (2) bound to the template before reconstitution, or (3) bound to the template after reconstitution (Fig. 4D, left). In contrast, the H1-containing chromatin to which Gal4-VP16 was prebound before reconstitution was more accessible to $X b a I$ digestion than H1-containing chromatin to which Gal4-VP16 was either added after reconstitution or omitted from the reactions (Fig. 4D, right). Thus, the $\mathrm{XbaI}$ accessibility data were nearly parallel to those of the transcriptional studies (Fig. 4A,B) - the ability of Gal4-VP16 to increase the accessibility of $\mathrm{XbaI}$ to its recognition site between the Gal4-binding sites and the TATA box was similar to its ability to increase the access of the basal transcriptional machinery to the chromatin templates.

The transcription and nuclease accessibility data indicate that the H1-containing and Hl-deficient chromatin possess distinct properties. In particular, we have found that preassembled H1-deficient chromatin is competent for Gal4-VP16-mediated activation of transcription, whereas preassembled $\mathrm{Hl}$-containing chromatin is transcriptionally inert. These transcriptional properties were also reflected by increased nuclease accessibility of $\mathrm{Hl}$ deficient chromatin relative to that of $\mathrm{Hl}$-containing chromatin. The transcriptional competence of Hl-deficient chromatin observed in this study is in accord with

A

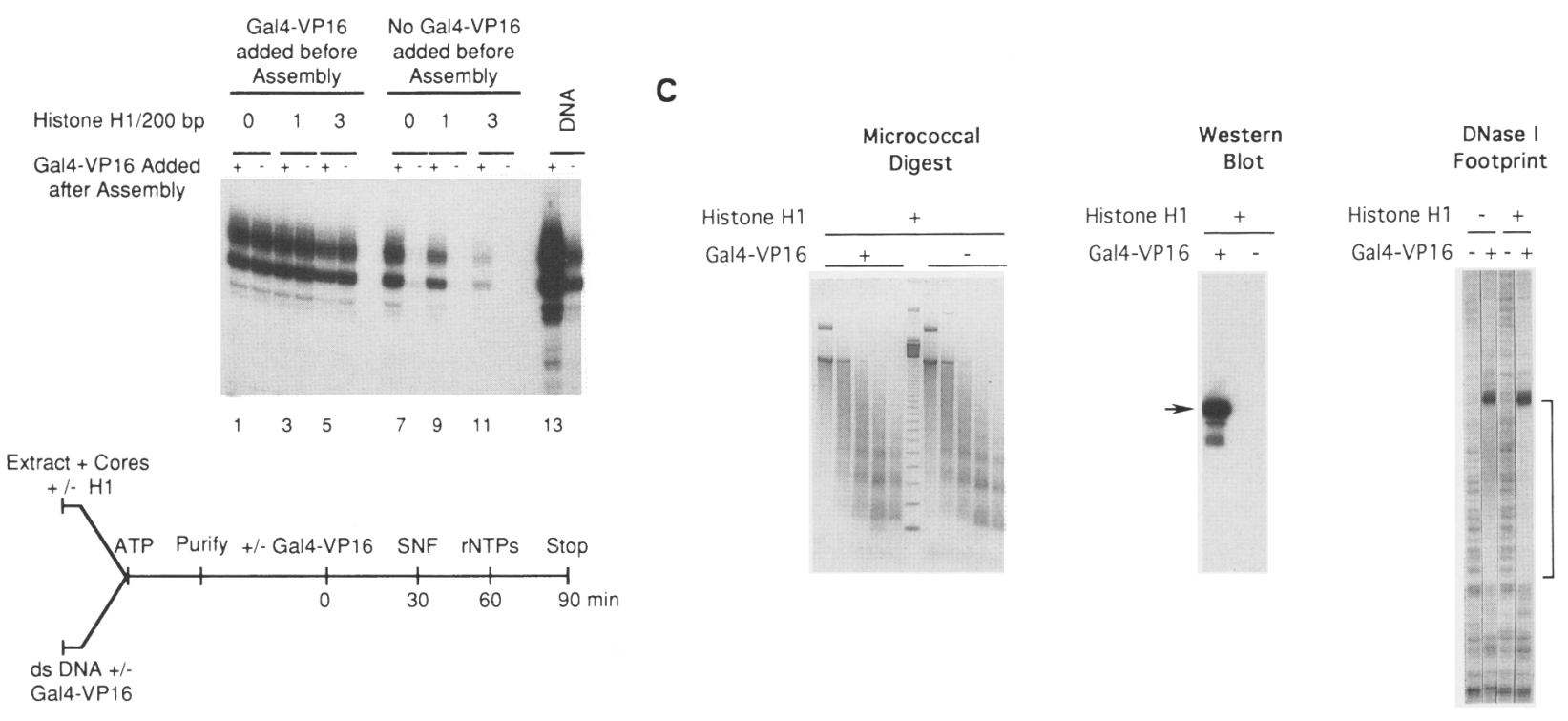

B

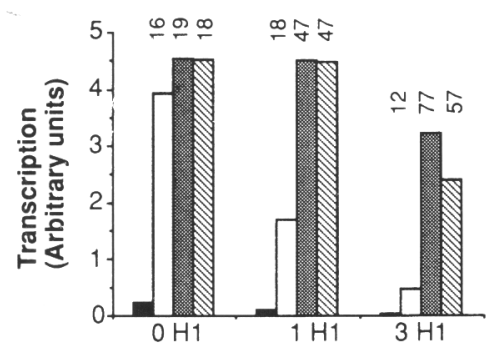

H1 Added during Assembly

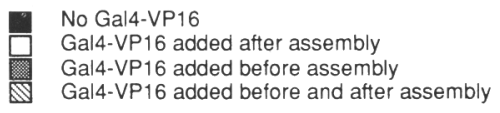

D
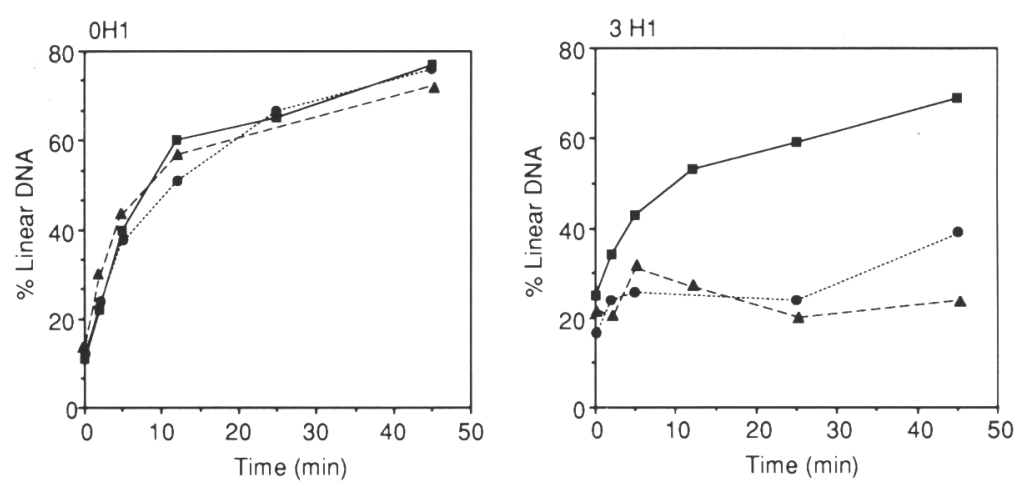

Figure 4. (See facing page for legend.) 
the results of Lorch et al. (1992), in which transcriptional repression by a nucleosomal core located over the RNA start site was relieved by binding of Gal4-VP16 upstream of the TATA box. These findings are also consistent with experiments showing that Gal4 derivatives can bind to reconstituted core particles [short DNA fragments ( 150 bp in length) wrapped around a core histone octamer in the absence of H1] (Taylor et al. 1991; Workman and Kingston 1992). We have found, however, that the behavior exhibited by H1-containing chromatin, which resembles native chromatin more closely in terms of its chemical and physical properties, is distinct from that of Hl-deficient chromatin. Unlike the H1-deficient chromatin, the H1-containing chromatin is refractory to transcription. In contrast to the conclusions of studies carried out with Hl-deficient chromatin, these results argue that Gal4-VP16 is not able to reconfigure the structure of native, H1-containing chromatin to allow gene activation according to the model depicted in Figure $1 \mathrm{C}$.

\section{Long-distance activation of transcription}

To characterize further the transcriptional properties of the Hl-containing chromatin, we examined long-distance activation of transcription with chromatin templates that were reconstituted with the Drosophila S-190 extract. In an earlier study, we had observed activation of transcription by Gal4-VP16 that was bound 1300 bp upstream of the TATA box of the adenovirus E4 promoter. This long-range activation occurred with $\mathrm{Hl}$-containing chromatin but not naked DNA templates (Laybourn and Kadonaga 1992). In the previous experiments, however, the chromatin was prepared with a purified, polyglutamate-based reconstitution system (Stein 1989; Laybourn and Kadonaga 1991) that did not yield chromatin with even nucleosomal spacing. Thus, we felt that it was important to investigate long-range activation of transcription with $\mathrm{H} 1$-containing chromatin that possessed regularly spaced nucleosomes. Hence, the Drosophila S-190 extract was used to reconstitute $\mathrm{Hl}$-containing chromatin onto $\mathrm{pG}_{5} \mathrm{E} 4-1000$ template DNA, which contained five Gal4-binding sites located $1000 \mathrm{bp}$ upstream of the TATA box of the adenovirus E4 promoter. As shown in Figure 5, long-range activation by Gal4-VP16 was observed with the H1-containing chromatin but not the corresponding naked DNA template, and the Gal4VP16-mediated stimulation of transcription was dependent on the presence of the Gal4-binding sites located $1000 \mathrm{bp}$ upstream of the TATA box. These results demonstrate that the long-range activation in vitro can be achieved with H1-containing chromatin possessing regularly spaced nucleosomes and further support the hypothesis that the packaging of DNA into chromatin is an important component in long-distance activation of transcription, such as the action of enhancers.

Although the present data do not reveal the precise mechanism of long-range activation of transcription, these experiments provide further evidence that enhancer-binding factors may function primarily to counteract chromatin-mediated repression at the proximal promoter in a process that probably involves interactions between the distally bound enhancer-binding factors and components of the basal transcriptional machinery. Consistent with this postulate, Gal4-VP16 located 1000 bp upstream of the TATA box did not stimulate tran-

Figure 4. Hl-containing and Hl-deficient chromatin possess distinct transcriptional properties. Chromatin was reconstituted from double-stranded, circular $\mathrm{pG}_{5} \mathrm{E} 4 \mathrm{Kr}$ DNA in the presence or absence of Gal4-VP16 with zero, one, or three molecules of exogenous histone $\mathrm{Hl}$ per 200-bp DNA, purified by sucrose gradient sedimentation, and then characterized by either in vitro transcription or restriction enzyme digestion assays. (A) Transcription of the chromatin templates. Gal4-VP16 protein was either omitted from the reactions or added to the DNA template before reconstitution, after sucrose gradient purification, or both before reconstitution and after purification of the chromatin, as designated in the scheme at the bottom. The resulting chromatin was subjected to in vitro transcription and primer extension analysis. The term SNF refers to the soluble nuclear fraction (Kamakaka et al. 1991), which was used as a source of basal transcription factors in the reactions. $(B)$ The results presented in $A$ were quantitated with a PhosphorImager, and the data are shown as a bar graph. The magnitude of transcriptional activation by Gal4-VP16 is indicated at the top. By comparison, the magnitude of transcriptional activation by Gal4-VP16 with the naked DNA template (Fig. 3A, lanes 13,14) was 12. (C) Studies of the binding of Gal4-VP16 to the reconstituted chromatin templates. Reconstitution reactions were carried out with three molecules of histone $\mathrm{Hl}$ per 200-bp DNA in the presence or absence of Gal4-VP16 under conditions identical to those used in the transcriptional analysis described in $A$. The resulting chromatin was then characterized as follows: (Left) Binding of Gal4-VP16 to DNA before chromatin reconstitution does not affect the bulk nucleosomal spacing. The reconstituted chromatin was partially digested with micrococcal nuclease, and the DNA fragments were analyzed by $1.5 \%$ agarose gel electrophoresis. (Middle) Gal4-VP16 remains bound to the chromatin after sucrose gradient sedimentation. Chromatin that was reconstituted in the presence or absence of Gal4-VP16 was purified by sucrose gradient sedimentation and then subjected to Western blot analysis with antibodies against the amino-terminal 147 amino acid residues of the yeast Gal4 protein. The arrow designates the position of Gal4-VP16. (Right) DNase I footprint analysis of Gal4-VP16 binding to the purified, reconstituted chromatin. Hl-containing or H1-deficient chromatin was reconstituted in the presence or absence of Gal4-VP16, purified by sucrose gradient sedimentation, and then subjected to DNase I and primer extension analysis (Gralla 1985; Croston et al. 1992). The region of the promoter that was protected by Gal4-VP16 is indicated by a bracket. (D) Binding of Gal4-VP16 before chromatin assembly increases restriction enzyme accessibility at the TATA box with $\mathrm{Hl}$-containing chromatin templates. The plasmid $\mathrm{pG}_{5} \mathrm{E} 4 \mathrm{Kr}$ has a unique $\mathrm{XbaI}$ restriction site located 6 bp downstream of the Gal4-binding sites and $7 \mathrm{bp}$ upstream of the TATA box of the adenovirus E4 promoter. The purified chromatin templates were digested with $\mathrm{XbaI}$ for the indicated times, and the resulting DNA samples were deproteinized and analyzed by agarose gel electrophoresis. The gels were photographed and the negatives were quantitated by scanning densitometry to yield the results that are presented in the graphs. 


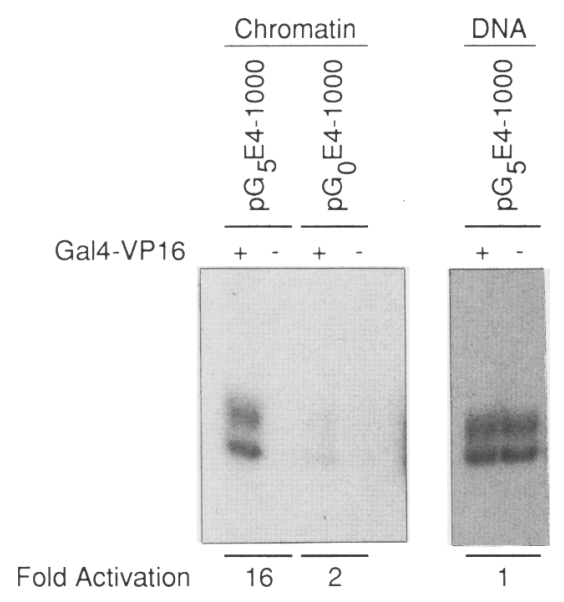

Figure 5. Long-range activation of transcription by Gal4-VP16 bound $1000 \mathrm{bp}$ upstream of the TATA box. Histone $\mathrm{Hl}$-containing chromatin was reconstituted with $\mathrm{pG}_{5} \mathrm{E} 4-1000$ or $\mathrm{pG}_{0} \mathrm{E} 4$ 1000 templates in the presence or absence of Gal4-VP16 and then transcribed along with the corresponding naked DNAs. In this experiment, Gal4-VP16 was added to the templates before reconstitution of chromatin. $\mathrm{pG}_{5} \mathrm{E} 4-1000$ was constructed by insertion of a 1000-bp fragment from the Drosophila TFIIB gene into $\mathrm{pG}_{5} \mathrm{E} 4 \mathrm{~T}$ (Lin et al. 1988) at the unique $\mathrm{XbaI}$ and $\mathrm{BamHI}$ sites located between the five tandem Gal4-binding sites and the TATA box of the adenovirus E4 promoter (M. Bulger and J.T. Kadonaga, unpubl.). $\mathrm{pG}_{0} \mathrm{E} 4-1000$ is identical to $\mathrm{pG}_{5} \mathrm{E} 4-1000$, except that it does not contain Gal4-binding sites.

scription with histone-free DNA templates (Fig. 5) [note, however, that under identical conditions, $\sim 8$ - to 10 -fold activation of transcription was observed with templates containing Gal4-binding sites located immediately upstream of the TATA box (see, e.g., Fig. 4)]. Moreover, recent studies of transcriptional activation in mouse preimplantation embryos, in which the function of distally bound enhancers can be distinguished from that of proximal promoters, also suggest that enhancers act primarily to relieve repression of promoters (Majumder et al. 1993). It is possible that the wrapping and folding of the DNA template that occurs with packaging into chromatin would bring the distally bound enhancer-binding factors into closer proximity of the TATA box and RNA start site and thus facilitate access of the basal transcriptional machinery to the proximal promoter. The analysis of long-distance activation of transcription in vitro is presently at an early stage, and the study of additional factors with different genes should illuminate the relevance, if any, of these proposed mechanisms for enhancer function.

\section{Transcriptional repression by histone $H 1$}

Thus far, the transcriptional analyses of the reconstituted chromatin templates have shown that the addition of Gal4-VP16 to the DNA templates before chromatin reconstitution can potentiate transcription from both short and long distances from the transcription start site and that preassembled $\mathrm{Hl}$-containing chromatin tem- plates are transcriptionally inert. We therefore sought to characterize the Hl-containing chromatin further, not only because it possesses properties similar to those of native chromatin but also because many studies performed in vivo (Nacheva et al. 1989; Kamakaka and Thomas 1990; Postnikov et al. 1991; Bresnick et al. 1992) and in vitro (Schlissel and Brown 1984; Shimamura et al. 1989a; Wolffe 1989; Croston et al. 1991a; Laybourn and Kadonaga 1991) have suggested that $\mathrm{Hl}$ functions as a transcriptional repressor.

To focus specifically on the role of $\mathrm{Hl}$ in chromatin, first we depleted histone $\mathrm{Hl}$ from reconstituted Hl-containing chromatin and then readded varying amounts of purified, exogenous $\mathrm{Hl}$ to the depleted chromatin in the presence or the absence of the Gal4-VP16 protein. Because the repeat length of $\mathrm{Hl}$-containing chromatin was $\sim 20$ bp longer than that of chromatin reconstituted in the absence of exogenous Hl (Fig. 2), we prepared H1deficient chromatin by depletion of H1-containing chromatin rather than reconstitution of chromatin in the absence of $\mathrm{Hl}$. To deplete $\mathrm{Hl}$ from the chromatin, we found that sedimentation of the Hl-containing chromatin in a sucrose gradient in the presence of $0.5 \mathrm{M} \mathrm{NaCl}$ resulted in efficient removal of $\mathrm{H} 1$ under conditions that maintained the integrity and regular spacing of the nucleosomes (Fig. 6A,B). Upon depletion of histone $\mathrm{Hl}$, there was a significant increase in transcriptional activity of the templates [13-fold in the absence of Gal4-VP16 (Fig. 6C, lanes 2,4); 27-fold in the presence of Gal4-VP16 (Fig. 6C, lanes 1,3)]. Hence, depletion of $\mathrm{H1}$ from the chromatin resulted in derepression of transcription. These findings are similar to those observed by Shimamura et al. (1989a) for transcription by RNA polymerase III with chromatin templates that were reconstituted with extracts derived from Xenopus oocytes.

Purified histone $\mathrm{Hl}$ was then reincorporated into the Hl-depleted chromatin by salt gradient dialysis (from 0.5 to $0.05 \mathrm{M} \mathrm{NaCl}$ ) in the presence or absence of Gal4-VP16 (Laybourn and Kadonaga 1991), and the samples were subjected to in vitro transcription analysis. These experiments tested the ability of Gal4-VP16 to counteract histone Hl-mediated inhibition of transcription with the regularly spaced nucleosomal templates. As shown in Figure 6, C and D, readdition of $\mathrm{Hl}$ to the H1-depleted templates repressed both basal and factor-activated transcription in parallel. Thus, under the conditions of the salt gradient dialysis, the reincorporation of histone $\mathrm{H} 1$ into the $\mathrm{Hl}$-depleted chromatin was more efficient than the binding of Gal4-VP16 in a transcriptionally productive manner. These data demonstrate that the binding of $\mathrm{H} 1$ to H1-depleted nucleosomal templates is distinct from that of $\mathrm{Hl}$ to naked DNA. For example, when Gal4-VP16 was added to preformed H1-DNA complexes, it was able to bind to the template DNA (as determined by DNase I footprinting/ and to relieve $\mathrm{H1}$ mediated inhibition of transcription (Croston et al. 1991a, G.E. Croston and J. T. Kadonaga, unpubl.).

In addition, these results are different from those obtained in similar, but nonidentical, experiments in which histone $\mathrm{H1}$ and Gal4-VP16 were simultaneously 


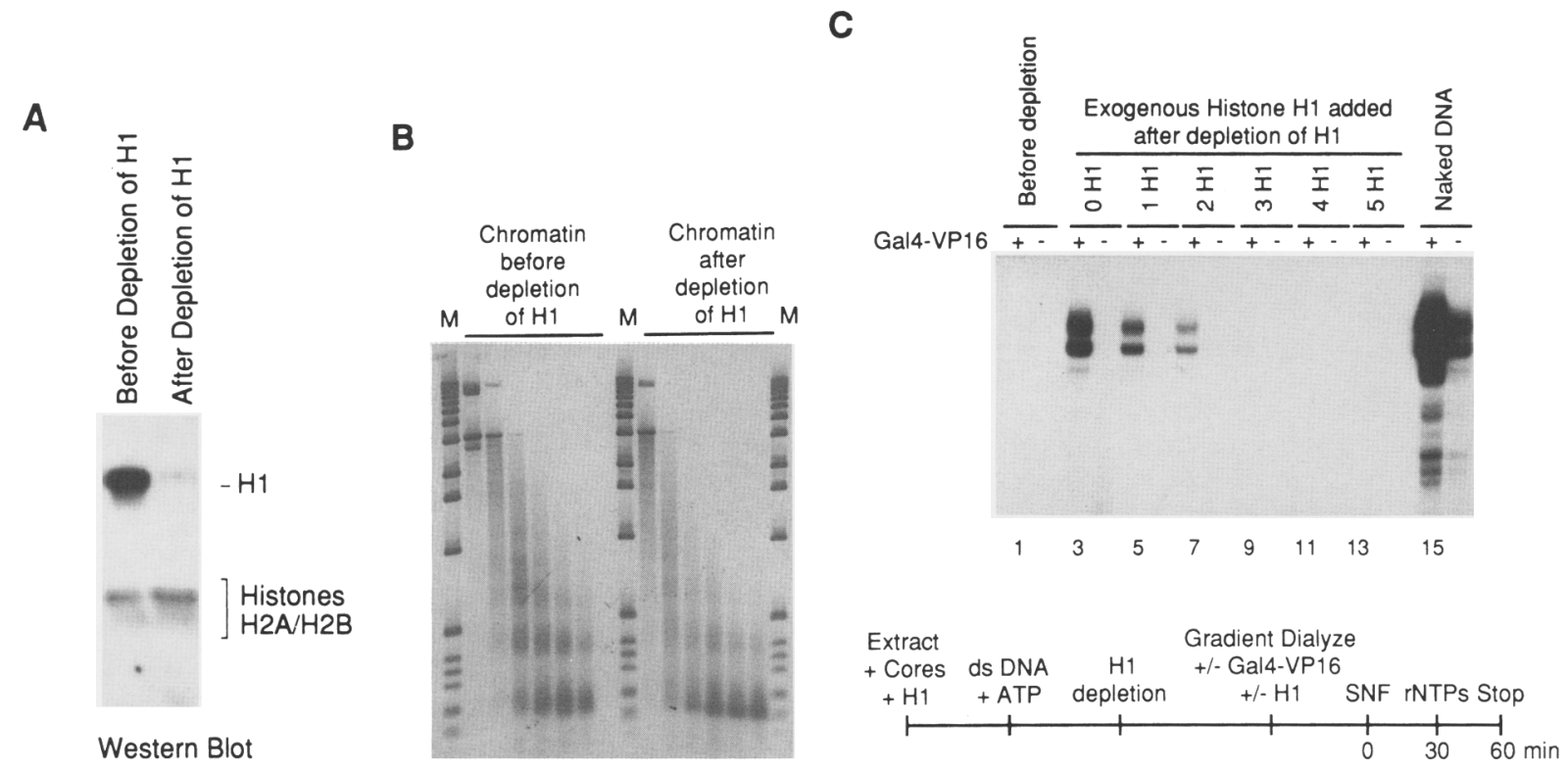

\section{D}

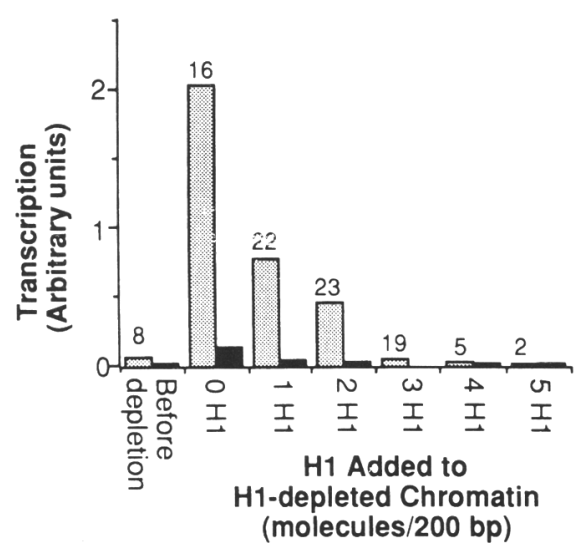

Figure 6. Histone $\mathrm{Hl}$ is preferentially incorporated into $\mathrm{Hl}$-depleted chromatin relative to Ga14-VP16. Chromatin was reconstituted onto $\mathrm{pG}_{5} \mathrm{E} 4 \mathrm{Kr}$ templates in the presence of three molecules of exogenous histone $\mathrm{H} 1$ per 200-bp DNA. Onehalf of the sample was purified by sucrose gradient sedimentation in a buffer containing $50 \mathrm{mM} \mathrm{NaCl}$ to give $\mathrm{Hl}$-containing chromatin; the other half of the sample was simultaneously purified and depleted of histone $\mathrm{Hl}$ by sucrose gradient sedimentation in a buffer containing $0.5 \mathrm{M} \mathrm{NaCl}$ to give $\mathrm{Hl}$-depleted chromatin. $(A)$ Depletion of histone $\mathrm{Hl}$ with sucrose gradient sedimentation in the presence of $0.5 \mathrm{M} \mathrm{NaCl}$. The proteins in the $\mathrm{H1}$-containing and $\mathrm{H} 1$-depleted chromatin samples were subjected to Western blot analysis with antibodies against Drosophila histone $\mathrm{H} 1$ and Drosophila histones $\mathrm{H} 2 \mathrm{~A}$ and $\mathrm{H} 2 \mathrm{~B}$ (as a control). (B) The nucleosomal spacing, as determined by micrococcal nuclease digestion analysis, was not altered by depletion of histone $H 1$. (C) Readdition of purified histone $\mathrm{Hl}$ to $\mathrm{H} 1$-depleted chromatin represses transcription in the presence or absence of the Gal4-VP16 activator protein. The H1-depleted chromatin was subjected to salt gradient dialysis from 0.55 to $0.05 \mathrm{M} \mathrm{KCl}$ (Laybourn and Kadonaga 1991) in the presence or absence of Gal4-VP16 (at an amount of 10 dimers per Gal4-binding site) and the indicated amounts of histone $\mathrm{Hl}$. The resulting chromatin samples were then transcribed in vitro. The term SNF refers to the soluble nuclear fraction (Kamakaka et al. 1991) that was used as a source of basal transcription factors in the reactions. $(D)$ The results presented in $C$ were quantitated with a PhosphorImager, and the data are shown as a bar graph. (Stippled bar) Gal4-VP16/ $\mathrm{H} 1$ coaddition; (solid bar) $\mathrm{Hl}$ addition. The magnitude of transcriptional activation by Gal4-VPl6 is indicated at the top. By comparison, the magnitude of transcriptional activation by Gal4-VP16 with the naked DNA template $(C$, lanes 15,16$)$ was 11 .

subjected to salt gradient dialysis with templates containing randomly distributed nucleosomes that were prepared by polyglutamate-mediated deposition of histone octamers (Laybourn and Kadonaga 1991). In the previous study, it was found that Gal4-VP16 was able to counteract histone Hl-mediated inhibition at low $1 \leqslant 1$ molecule/200-bp DNA), but not at higher ( $\geqslant 1.5$ molecules of $\mathrm{Hl} / 200-\mathrm{bp}$ DNA) concentrations of H1. Given the differences in the properties of the chromatin preparations used in these experiments, especially with regard to the nucleosomal spacing and the reagents/extracts used for chromatin reconstitution, it is not surprising to find differences in the binding of $\mathrm{Hl}$ to the nucleosomal templates. It is likely, for instance, that the affinity of $\mathrm{H} 1$ for the regularly spaced H1-depleted chromatin is higher than that of chromatin consisting of randomly distributed nucleosomal cores. This higher affinity might then account for the more effective binding and transcriptional repression by histone $\mathrm{Hl}$ with the evenly spaced chromatin.

Thus, these studies have shown that $\mathrm{Hl}$ functions to repress transcription with the regularly spaced chromatin. When $\mathrm{Hl}$ was depleted from the chromatin under conditions that maintained even nucleosomal spacing, simultaneous addition of Gal4-VP16 and H1 to the nucleosomal templates resulted in preferential reincorporation of $\mathrm{Hl}$ into the chromatin rather than binding of Gal4-VP16 in a transcriptionally productive manner. In 
the context of the mechanisms of gene activation, these findings suggest that depletion of $\mathrm{Hl}$ can increase transcriptional activity, but the underlying events that lead to the establishment and maintenance of the activated state, which are addressed in the following section, appear to be more complex than the addition of the Gal4VP16 activator.

\section{Potentiation of transcription by Gal4-VP16 during DNA replication and chromatin assembly}

The role of chromatin structure in the regulation of gene expression is particularly important to consider in the analysis of the early steps in gene activation. How are transcriptionally repressed genes rendered transcriptionally competent or active? As discussed in the introductory section (Fig. 1), transcriptional activation may involve DNA replication-dependent or -independent mechanisms for the reconfiguration of repressed chromatin structure to allow access of transcription factors to the template DNA. In this study, we have carried out biochemical experiments to address the relative importance of these two mechanisms with a simple transcriptional activator, Gal4-VP16. First, we have observed that nucleosomal templates deficient in histone $\mathrm{Hl}$ were readily activated by Gal4-VP16. These findings alone, which were consistent with the results of other studies on Gal4-VP16 binding to chromatin in the absence of $\mathrm{H} 1$ (Taylor et al. 1991; Lorch et al. 1992; Workman and Kingston 1992), suggested that the Gal4-VP16 transcription factor possesses the ability to reconfigure nucleosome structure to facilitate gene activation in the absence of DNA replication (Fig. 1C). Yet, in contrast to the findings with the Hl-deficient chromatin, we have found that preestablished H1-containing chromatin, which is probably a more accurate model for the chromatin structure of genes in vivo than H1-deficient chromatin, is refractory to transcriptional activation by Gal4-VP16. Thus, it appears that DNA replication is required for the disruption of chromatin structure that would then allow access of Gal4-VP16 to the DNA template (Fig. 1A).

To test this model of gene activation, we mimicked DNA replication and chromatin assembly at a replication fork by carrying out DNA synthesis of the complementary strand of single-stranded M13 DNA and chromatin assembly with the Drosophila S-190 extract (Fig. 7A,B). Micrococcal nuclease digestion analysis of the resulting chromatin revealed that the nucleosomal repeat length of chromatin reconstituted in the presence of zero or one molecule of exogenously added $\mathrm{Hl}$ per 200-bp DNA was $173 \mathrm{bp}$ or $188 \mathrm{bp}$, respectively (Fig. 7B). The existence of the replication/assembly activities in the Drosophila extract was not surprising because it had been shown previously that similar extracts from Xenopus oocytes (Almouzni and Méali 1988) and preblastoderm Drosophila embryos (Becker and Wu 1992) were competent for DNA replication (beginning with singlestranded M13 DNA) and chromatin assembly. In addition, as observed previously with other replication/assembly systems (Almouzni and Méali 1988; Becker and Wu 1992), DNA replication and chromatin assembly occurred at a faster rate than the reconstitution of chromatin from double-stranded DNA, which suggests that the replication and assembly processes are coupled. Finally, to address the possible role of DNA repair (DNA polymerase $\beta$ ) activity in this process, we examined aphidicolin sensitivity of the replication reaction. In contrast to the properties of Drosophila DNA polymerase $\beta$ /Sakaguchi and Boyd 1985), which is resistant to aphidicolin, the single-stranded DNA to double-stranded DNA replication activity with S-190 is inhibited by $7 \mu \mathrm{g} / \mathrm{ml} / \sim 50 \%$ remaining activity) and $40 \mu \mathrm{g} / \mathrm{ml}(<15 \%$ activity) aphidicolin. Thus, it is unlikely that DNA polymerase $\beta$ is responsible for the conversion of the single-stranded DNA to double-stranded DNA.

The transcriptional analysis was then performed as follows (Fig. 7C,D). DNA replication/chromatin assembly reactions were carried out with the indicated amounts of histone $\mathrm{Hl}$ (in molecules of H1/200-bp

Figure 7. Potentiation of transcription by Gal4-VP16 during DNA replication and chromatin assembly. Single-stranded M13G E4 $_{5}$ DNA was incubated with the Drosophila embryo extract, core histones, histone $\mathrm{Hl}$ (where indicated), an ATP-regenerating system, an oligodeoxyribonucleotide primer, and the four $2^{\prime}$-deoxyribonucleoside $5^{\prime}$-triphosphates to yield double-stranded DNA packaged into chromatin. $(A)$ Replication of single-stranded $\mathrm{Ml3G}_{5} \mathrm{E} 4 \mathrm{DNA}$ with the Drosophila S-190 extract. After DNA replication and chromatin assembly, the chromatin samples were deproteinized and analyzed by agarose gel electrophoresis. The positions of singlestranded DNA, double-stranded DNA, and nicked double-stranded DNA are indicated. $(B)$ Micrococcal nuclease digestion analysis of chromatin prepared by DNA replication and chromatin assembly in the presence or absence of exogenous histone H1. (C) Transcription of templates after DNA replication and chromatin assembly. Gal4-VP16 protein was either omitted from the reactions or included during replication/assembly, after replication/assembly/purification, or both during replication/assembly and after replication/assembly/purification, as outlined in the scheme at the bottom. The resulting chromatin was subjected to in vitro transcription (50 ng of DNA/reaction) and primer extension analysis. As a control, single-stranded $\mathrm{Ml}_{3} \mathrm{G}_{5} \mathrm{E} 4$ virion DNA (50 ng), deproteinized chromatin after replication/assembly/purification (containing $50 \mathrm{ng}$ DNA), and double-stranded M13G 54 RF DNA (50 ng) were transcribed in the presence or absence of Gal4-VP16 (lanes 13-18). The term SNF refers to the soluble nuclear fraction (Kamakaka et al. 1991) that was used as a source of basal transcription factors in the reactions. $(D)$ The results presented in $C$ were quantitated with a PhosphorImager, and the data are shown as a bar graph. The magnitude of transcriptional activation by Gal4-VP16 is indicated at the top. $(E)$ Transcriptional potentiation by Gal4-VP16 during DNA replication and chromatin assembly is dependent on the presence of Gal4-binding sites in the promoter. Reactions were carried out as described in lanes 5 and 6 of $C$, above, with either single-stranded

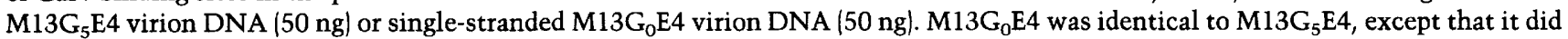
not contain Gal4-binding sites. 
DNA), and the resulting double-stranded chromatin templates were purified by sucrose gradient sedimentation and transcribed in vitro. The template DNA, M13 $\mathrm{G}_{5} \mathrm{E} 4$, is related to $\mathrm{pG}_{5} \mathrm{E} 4 \mathrm{Kr}$ and contains five Gal4binding sites located $19 \mathrm{bp}$ upstream of the TATA box of the adenovirus E4 promoter. The Gal4-VP16 activator was (1) omitted from the reactions, (2) added to the template during replication/assembly, (3) added after sucrose gradient purification, or (4) added both during replication/assembly and after purification. As control/reference experiments, single-stranded $\mathrm{M}_{13} \mathrm{G}_{5} \mathrm{E} 4 \mathrm{DNA}$ was found to be transcriptionally inactive (Fig. 7C, lanes $13,14)$, whereas double-stranded $\mathrm{M}^{3} \mathrm{G}_{5} \mathrm{E} 4 \mathrm{RF}$ DNA was transcribed with similar efficiency as double-stranded $\mathrm{M}_{3} \mathrm{G}_{5} \mathrm{E} 4 \mathrm{DNA}$ that was prepared by replication/assembly in vitro followed by deproteinization (Fig. 7C, lanes

\section{C}

A

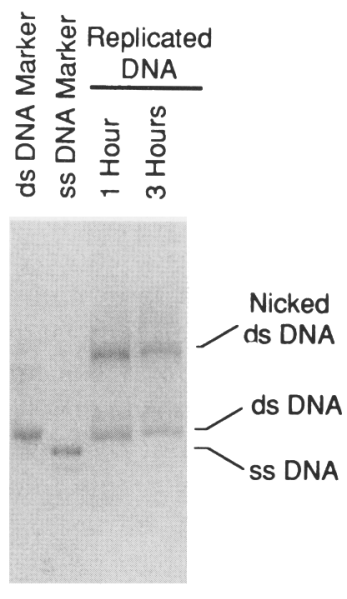

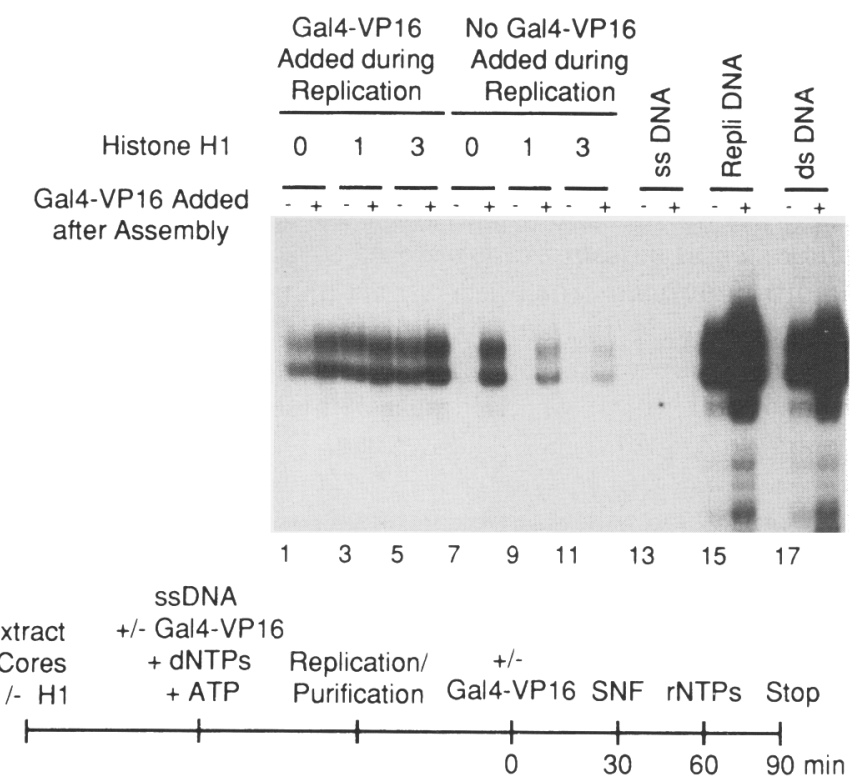

D

B

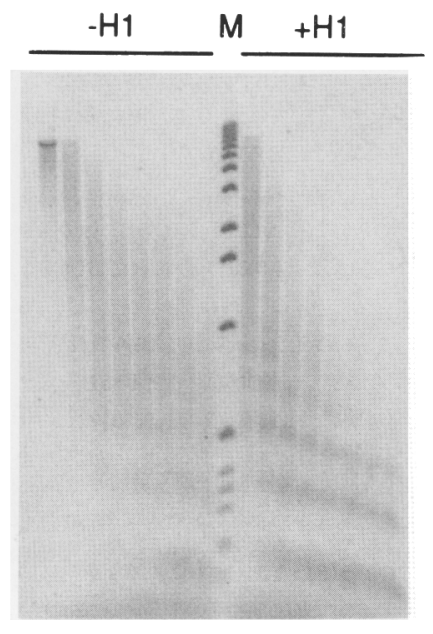

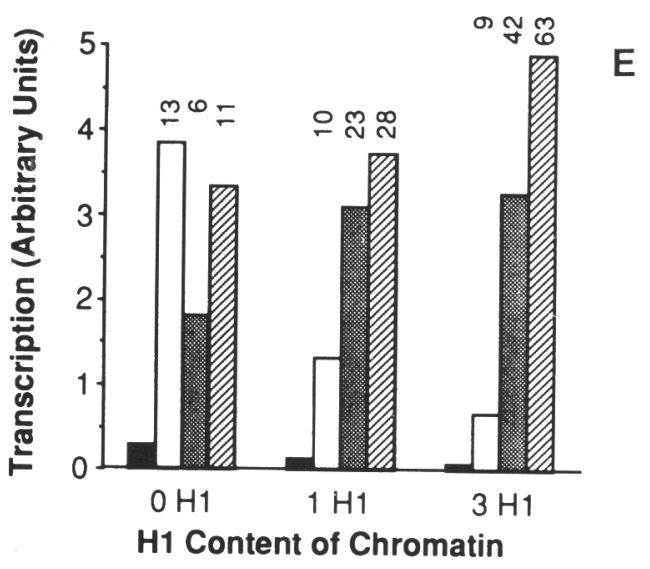

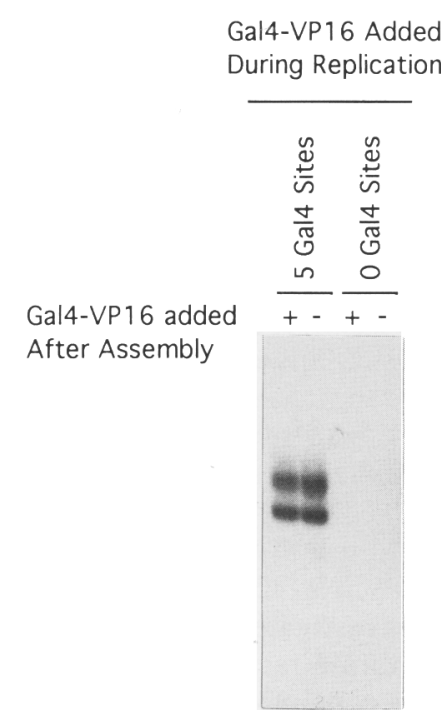

No Gal4-VP16 added

Gal4-VP16 added after replication

Gal4-VP16 added during replication

Gal4-VP16 added during and after replication

Figure 7. (See facing page for legend.) 
15-18). In the absence of Gal4-VP16, there was a 51-fold repression of transcription with replication/assembly in the absence of $\mathrm{Hl}$ (Fig. 7C, lanes 8,15) and a 200-fold repression of transcription with replication/assembly in the presence of $\mathrm{Hl}$ (Fig. 7C, lanes 11,15).

In the reactions where Gal4-VP16 was added after replication/assembly, the results were virtually identical to those obtained when Gal4-VP16 was added after reconstitution of chromatin with double-stranded $\mathrm{pG}_{5} \mathrm{E} 4 \mathrm{Kr}$ DNA (Fig. 4A, lanes 7-12, and B). The H1-deficient chromatin was transcriptionally competent, whereas the $\mathrm{Hl}$ containing chromatin was repressed (Fig. 7C, lanes 7-12, and D). Hence, the transcriptional properties of chromatin prepared by replication/assembly from singlestranded DNA were nearly identical to those of chromatin reconstituted from double-stranded DNA.

When Gal4-VP16 was present during the replication/ assembly reactions, it was able to counteract the chromatin-mediated repression to a comparable extent whether $\mathrm{Hl}$-deficient or $\mathrm{Hl}$-containing chromatin was synthesized (Fig. 7C, lanes 1-6, and D). The magnitude of activation by Gal4-VP16 increased from 4- to 5-fold with naked double-stranded DNA (Fig. 7C, lanes 15-18) to 43-fold with the $\mathrm{H1}$-containing chromatin (Fig. 7C, lanes 6,11, and D). In addition, the Gal4-VP16-mediated activation observed after replication/assembly was found to be dependent on the presence of Gal4-binding sites in the template DNA (Fig. 7E). Thus, we have been able to demonstrate potentiation of transcription by Gal4-VP16 during but not after DNA replication and assembly of histone $\mathrm{Hl}$-containing chromatin.

These experiments provide biochemical data that support a DNA replication-dependent mechanism (Fig. 1A) and argue against a DNA replication-independent mechanism (Fig. 1C) for reconfiguration of chromatin structure and activation of transcription by the Gal4-VP16 protein. In addition, the presence or absence of histone $\mathrm{H} 1$ in the chromatin templates was an important facet of these studies, as contrary results were obtained when H1-deficient chromatin templates were used instead of $\mathrm{Hl}$-containing chromatin. Because the H1-containing chromatin possessed chemical and physical features that were similar to those of native chromatin, in the interpretation of the experiments we have presumed that the transcriptional properties of the $\mathrm{H1}$-containing chromatin were more likely to reflect the behavior of native chromatin in vivo than those of the Hl-deficient chromatin. Finally, it is important to consider that our data can also be explained by a replication-independent mechanism of transcriptional activation if there were a chromatin modification activity in the crude S-190 extract that facilitated the ability of Gal4-VP16 to counteract chromatin-mediated repression. This hypothetical activity might function, for instance, to mobilize $\mathrm{Hl}$ containing nucleosomes. Although no evidence exists for such an activity, it would nevertheless be worthwhile to investigate the possible existence of nucleosome mobilization factors.

In conclusion, we suggest that it is important to consider, but not to overemphasize the role of DNA repli- cation in gene activation. Most genes that are induced rapidly will probably have developed replication-independent mechanisms for transcriptional activation. With some genes, such as Drosophila hsp70 (Rougvie and Lis 1988), the chromatin structure would be established in a preactivated state before induction (Fig. 1B). With other genes, such as the mouse mammary tumor virus LTR promoter (Richard-Foy and Hager 1987) and the yeast PHO5 gene (Schmid et al. 1992), replicationindependent alteration of chromatin structure and transcriptional activation would occur (Fig. 1C). With regard to the latter genes, however, it is interesting to note that induction of the mouse mammary tumor virus LTR promoter by the glucocorticoid receptor results in depletion of histone $\mathrm{Hl}$ at the promoter region (Bresnick et al. 1992) and that yeast strains do not appear to possess histone $\mathrm{H} 1$. This correlation between replication-independent reconfiguration of chromatin structure and the loss or absence of histone $\mathrm{Hl}$ suggests that the depletion or alteration of $\mathrm{H} 1$ may be an early step in gene activation. Moreover, there might be a specialized class of transcription factors, perhaps including the glucocorticoid receptor (Perlmann and Wrange 1988; Piña et al. 1990; Archer et al. 1991), that possess the ability to disrupt the chromatin structure of genes. Finally, it is also important to state explicitly that the experiments described in this study are a biochemical approximation of events in the cell, and thus, such issues as the rate of chromatin assembly after DNA replication may not be accurately reproduced in vitro. In spite of these potential imperfections, however, this work provides an early step toward the biochemical analysis of the relation between DNA replication and gene regulation. Amid the complexity of the analysis of chromatin structure, further analysis of both replication-dependent and -independent mechanisms of transcriptional activation should provide important new insight into the regulation of gene expression in eukaryotes.

\section{Materials and methods}

\section{Purification of proteins}

Core histones were purified from Drosophila embryos (collected between 0 and $12 \mathrm{hr}$ after fertilization) as described by Laybourn and Kadonaga (1991). Histone $\mathrm{Hl}$ was purified from Drosophila embryos (collected between 0 and $12 \mathrm{hr}$ after fertilization) according to the procedure of Croston et al. (1991a,b). Gal4-VP16 (Sadowski et al. 1988) was expressed in Escherichia coli and purified to $\sim 75 \%$ homogeneity by the method of Chasman et al. (1989).

Preparation of the Drosophila S-190 extract for chromatin reconstitution

This procedure was developed over the course of $>100$ preparations of extracts each from $30-50$ grams of embryos. Canton-S wild-type flies were grown at $25^{\circ} \mathrm{C}$ at $70-80 \%$ humidity in population cages. The embryos were collected on molasses-agar plates covered with yeast.

Four batches of embryos [typically, 30-50 grams; collected (every $6 \mathrm{hr}$ over a 24-hr period) between 0 and $6 \mathrm{hr}$ after fertil- 
ization and then stored for $\leqslant 18 \mathrm{hr}$ at $4^{\circ} \mathrm{Cl}$, were harvested in nylon mesh with water and then dechorionated by immersion for $90 \mathrm{sec}$ in $1: 1$ (vol/vol) bleach [5.25\% (wt/vol) sodium hypochlorite]/water [final concentration of sodium hypochlorite is $2.63 \%(\mathrm{wt} / \mathrm{vol})]$ at room temperature. The embryos were quickly rinsed with embryo wash buffer I [ 1 liter; $0.7 \%$ (wt/vol) $\mathrm{NaCl}$ and $0.04 \%$ (vol/vol) Triton X-100; buffer at room temperature], washed with water (at room temperature), and transferred to a 800-ml beaker in an ice bath. Embryo wash buffer II [500 ml; buffer at $4^{\circ} \mathrm{C} ; 0.7 \%(\mathrm{wt} / \mathrm{vol}) \mathrm{NaCl}$ and $0.05 \%$ (vol $\left./ \mathrm{vol}\right)$ Triton X-100] was added to the beaker. The embryos were suspended with a glass rod and allowed to settle to the bottom of the beaker (for $\sim 2 \mathrm{~min}$ ). The cloudy suspension above the embryos, which contained chorion particles and other debris, was removed by aspiration. This wash/settling/aspiration procedure was repeated once with embryo wash buffer II $(500 \mathrm{ml}$; at $4^{\circ} \mathrm{C}$, twice with $0.7 \%$ (wt/vol) $\mathrm{NaCl}$ solution $(500 \mathrm{ml}$ for each wash; buffer at $\left.4^{\circ} \mathrm{C}\right]$, and once with buffer $\mathrm{R}[500 \mathrm{ml}$; buffer at $4^{\circ} \mathrm{C} ; 10 \mathrm{mM}$ HEPES $\left(\mathrm{K}^{+}\right)(\mathrm{pH} 7.5), 10 \mathrm{mM} \mathrm{KCl}, 1.5 \mathrm{mM} \mathrm{MgCl}_{2}, 0.5$ mM EGTA, $10 \%$ (vol/vol) glycerol, $10 \mathrm{~mm} \beta$-glycerophosphate, $1 \mathrm{~mm}$ DTT, $0.2 \mathrm{mM}$ phenylmethylsulfonyl fluoride (PMSF)]. In the final wash, the embryos take longer to settle $(\sim 10 \mathrm{~min})$, and the final volume of the embryo suspension before homogenization is roughly twice of that of the loosely packed volume of dechorionated embryos. The embryos were then transferred to a Wheaton Dounce homogenizer $(40 \mathrm{ml})$ and disrupted by 15 strokes with the B pestle followed by 40 strokes with the A pestle. The homogenate was subjected to centrifugation in a Falcon 2059 tube in a Sorvall SS-34 rotor at $8000 \mathrm{rpm}$ for $5 \mathrm{~min}$ at $4^{\circ} \mathrm{C}$. The cloudy, yellow cytoplasmic fraction was collected with a syringe / the white layer at the top and the pellet at the bottom of the tube were avoided). $\mathrm{MgCl}_{2}$ (from a $1 \mathrm{M}$ stock solution/ was added to increase the $\mathrm{Mg}(\mathrm{II})$ concentration from $1.5 \mathrm{~mm}$ to a final concentration of $7 \mathrm{mM}$. The extract was then subjected to centrifugation in a Beckman SW55 rotor at 45,000 $\mathrm{rpm}(192,000 \mathrm{~g})$ for $2 \mathrm{hr}$ at $4^{\circ} \mathrm{C}$. After centrifugation, the white upper layer was removed with a spatula and the yellow-brown liquid was collected. This supernatant fraction was frozen in liquid nitrogen, thawed in water (at room temperature), and then subjected to a second centrifugation in the Beckman SW55 rotor at $45,000 \mathrm{rpm}$ for $2 \mathrm{hr}$ at $4^{\circ} \mathrm{C}$. The resulting chromatin reconstitution extract (also referred to as the Drosophila S-190 extract) was frozen in liquid nitrogen and stored at $-80^{\circ} \mathrm{C}$. The extracts remain active for $>1$ year at $-80^{\circ} \mathrm{C}$.

\section{Reconstitution of chromatin onto double-stranded DNA}

The Drosophila S-190 extract was competent for reconstitution of chromatin from either circular or linear double-stranded DNA. The extracts contained low levels of core histones, and it was necessary to supplement the extract with exogenous core histones to reconstitute nucleosomal cores with high efficiency. The optimal amount of core histones to be added to each extract was determined empirically. The S-190 extracts also contained low levels of histone $\mathrm{H} 1$. Hence, it was necessary to add exogenous $\mathrm{Hl}$ to the reaction medium to reconstitute $\mathrm{Hl}$ containing chromatin.

A typical reconstitution reaction was performed as follows. S-190 extract $(7 \mathrm{mg}$, which is $\sim 275 \mu \mathrm{l})$ was incubated at $27^{\circ} \mathrm{C}$ for 30 min with Drosophila core histones $(2-3 \mu \mathrm{g})$ and Drosophila histone $\mathrm{Hl}$ (when desired) in buffer $\mathrm{R}$ in a total volume of 450 $\mu l$. This mixture was then used in the reconstitution reaction (500 $\mu$ l final volume) containing plasmid DNA $(5 \mu \mathrm{g})$, ATP $(3$ $\mathrm{mM})$, creatine phosphate ( $30 \mathrm{~mm}$; Sigma cat. no. P 6502), creatine kinase ( $1 \mu \mathrm{g} / \mathrm{ml}$; Sigma cat. no. C 3755), and Gal4-VP16 (500 $\mathrm{nM}$, where indicated). The $\mathrm{MgCl}_{2}$ concentration was also adjusted to $7 \mathrm{~mm}$. The reaction was carried out at $27^{\circ} \mathrm{C}$ for $5 \mathrm{hr}$ and then terminated by the addition of EDTA to $20 \mathrm{~mm}$ final concentration.

\section{DNA replication and chromatin assembly}

The reaction conditions for DNA replication and chromatin assembly beginning with single-stranded M13 DNA were similar to those used for reconstitution of chromatin with doublestranded DNA. The single-stranded DNA used in these experiments was the viral form of $\mathrm{Ml}_{3} \mathrm{G}_{5} \mathrm{E} 4 \mathrm{DNA}$. $\mathrm{M} 13 \mathrm{G}_{5} \mathrm{E} 4$ was constructed by insertion of the 446-bp EcoRI-HindIII fragment of $\mathrm{pG}_{5} \mathrm{E} 4 \mathrm{~T}$ [Lin et al. 1988; this EcoRI-HindIII fragment contains five Gal4-binding sites upstream of the TATA box of the adenovirus E4 promoter (from -38 to +250 relative to the RNA start site)] into the EcoRI and HindIII sites of M13mp19 RF DNA. The Drosophila S-190 extract $(7 \mathrm{mg}$, which is $\sim 275 \mu \mathrm{l})$ was incubated at $27^{\circ} \mathrm{C}$ for $30 \mathrm{~min}$ in buffer R with Drosophila core histones $(2-3 \mu \mathrm{g})$ and Drosophila histone $\mathrm{H} 1$ (where indicated) in a total volume of $400 \mu \mathrm{l}$. Meanwhile, an oligonucleotide primer (AdE4 primer; 5 pmoles; Kerrigan et al. 1991), which is complementary to the adenovirus $\mathrm{E} 4$ sequences in the viral form of $\mathrm{Ml}_{3} \mathrm{G}_{5} \mathrm{E} 4 \mathrm{DNA}$, was annealed to the singlestranded DNA $(2.5 \mu \mathrm{g}=1 \mathrm{pmole})$ for $5 \mathrm{~min}$ each at $75,58,37$, and $27^{\circ} \mathrm{C}$. The resulting DNA sample was combined with the Drosophila extract-histone mixture along with the four 2 '-deoxyribonucleoside $5^{\prime}$-triphosphates $(0.125 \mathrm{~mm}$ of each), ATP (3 $\mathrm{mM})$, creatine phosphate $(30 \mathrm{~mm})$, creatine kinase $(0.1 \mu \mathrm{g} / \mathrm{ml})$, and Gal4-VP16 (500 nM, where indicated) in a final volume of $500 \mu \mathrm{l}$. The reactions were carried out for $3 \mathrm{hr}$ at $27^{\circ} \mathrm{C}$ and then terminated by the addition of EDTA to a final concentration of $20 \mathrm{~mm}$.

\section{Purification of reconstituted chromatin by sucrose gradient centrifugation}

Reconstituted chromatin was purified by $30-50 \%$ (wt/vol) sucrose gradient sedimentation in a Beckman SW41 rotor at $26,000 \mathrm{rpm}$ for $16 \mathrm{hr}$ at $4^{\circ} \mathrm{C}$. Typically, 3-4 ml of sample was applied to each SW41 tube. The buffer medium was $10 \mathrm{~mm}$ HEPES $\left(\mathrm{K}^{+}\right)$(pH 7.5), $1 \mathrm{mM}$ EDTA, $35 \mathrm{~mm} \mathrm{NaCl}, 0.2 \mathrm{~mm}$ PMSF, $0.5 \mathrm{mM}$ benzamidine- $\mathrm{HCl}$, and $5 \mu \mathrm{g} / \mathrm{ml}$ aprotinin (U.S. Biochemical cat. no. 11388 ) containing from $30-50 \%$ (wt/vol) sucrose. A portion $(40 \mu \mathrm{l})$ of each of the gradient fractions $(1 \mathrm{ml})$ was deproteinized and analyzed by $1 \%$ agarose gel electrophoresis and ethidium bromide staining to determine the location of the reconstituted chromatin.

\section{Micrococcal nuclease analysis of reconstituted chromatin}

Partial digestion of chromatin with micrococcal nuclease was carried out in $3 \mathrm{mM} \mathrm{CaCl}$ with empirically determined concentrations of nuclease for varying periods. In the analysis of chromatin in a crude extract, the medium was adjusted to $3 \mathrm{mM}$ $\mathrm{CaCl}_{2}$ before the termination of the reconstitution reaction with EDTA. Then, micrococcal nuclease (Sigma cat. no. N 5386) was added to the sample to a final concentration of 0.6 $\mathrm{U} / \mathrm{ml}$, and the digestion was carried out at $25^{\circ} \mathrm{C}$ from 2 to 45 min before termination of the reaction with $20 \mathrm{mM}$ EDTA. The samples were treated sequentially with $\mathrm{RNase} A$ and proteinase $\mathrm{K}$, and the resulting DNA fragments were deproteinized and then analyzed by $1.5 \%$ agarose gel electrophoresis. Micrococcal nuclease digestion of purified chromatin preparations were carried out with a nuclease concentration of $\sim 0.06 \mathrm{U} / \mathrm{ml}$. 


\section{Electron microscopy}

Chromatin was reconstituted onto $\mathrm{pG}_{5} \mathrm{E} 4 \mathrm{Kr}$ DNA in the presence of either zero or two molecules of exogenous Drosophila histone $\mathrm{Hl}$ per 200 bp DNA. The resulting chromatin was purified by $30-50 \%$ sucrose gradient sedimentation and then subjected to buffer exchange on a Sepharose CL-4B column (Bio-Rad Poly-Prep 2-ml column; $0.8 \mathrm{~cm}$ diam. $\times 4 \mathrm{~cm}$ length; $100 \mu \mathrm{l}$ sample applied to the $2-\mathrm{ml}$ column) at $4^{\circ} \mathrm{C}$ into $5 \mathrm{~mm}$ triethanolamine- $\mathrm{HCl}$ ( $\mathrm{pH} 7.0), 0.2 \mathrm{~mm}$ EDTA buffer [which is identical to the buffer conditions used by Thoma et al. (1979) to examine the extended $10 \mathrm{nM}$ chromatin filament]. Peak fractions from the Sepharose column were fixed with $0.4 \%$ (vol/vol) glutaraldehyde, $0.4 \%$ (vol/vol) formaldehyde for $2 \mathrm{hr}$. Copper grids 1400 mesh) coated with carbon film were floated for $10 \mathrm{~min}$ on a solution of $0.002 \%$ (wt/vol) Alcian blue, washed with water, and blotted dry. The fixed chromatin sample $(5 \mu \mathrm{l}$, not diluted) was placed on the grids for $10 \mathrm{~min}$. The grids were then washed twice for $5 \mathrm{~min}$ by floating on water. Low angle $\left(7^{\circ}\right)$ rotary shadowing with $80: 20 \mathrm{Pt} / \mathrm{Pd}$ was used for contrast enhancement. Grids were viewed with a Philips EM 300 microscope and photographed at 20,520 - or 26,260 -fold magnification.

\section{Other methods used for the analysis of the reconstituted chromatin}

Topological analysis of chromatin reconstituted onto $\mathrm{pG}_{5} \mathrm{E} 4 \mathrm{~T}$ (Lin et al. 1988) by two-dimensional agarose gel electrophoresis was carried out in the absence of chloroquine in the first dimension and in the presence of $4.1 \mu \mathrm{M}$ chloroquine in the second dimension, as described previously (Peck and Wang 1983; Shimamura et al. 1988; Laybourn and Kadonaga 1991). The topological marker was prepared by the method of Keller (1975). In these experiments, it is important to note that the S-190 extract contains high levels of topoisomerase I activity. High resolution agarose gel electrophoresis (Fig. 2C) was performed with $4 \%$ (wt/vol) agarose consisting of a $3: 1$ (wt/wt) mixture of NuSieve GTG agarose (FMC) and agarose (Bio-Rad) in a Trisacetate buffer. Native nucleoprotein gel electrophoresis of core particles and chromatosomes generated by micrococcal nuclease digestion of reconstituted chromatin was carried out with a $5 \%$ polyacrylamide gel by the method of Varshavsky et al. (1976), except that $1 \times$ TBE buffer was used for electrophoresis. The protein composition of the sucrose gradient-purified chromatin was analyzed by precipitation of the proteins with $25 \%$ (wt/vol) trichloroacetic acid followed by $18 \%$ polyacrylamide-SDS gel electrophoresis according to the procedure of Thomas and Kornberg (1978). Quantitative Western blotting was performed as described by Kamakaka and Thomas (1990). Salt gradient dialysis of chromatin to incorporate purified histone $\mathrm{Hl}$ was carried out by the method of Laybourn and Kadonaga (1991).

\section{In vitro transcription analysis}

In vitro transcription reactions and primer extension analysis were carried out as described previously (Kadonaga 1990; Wampler et al. 1990; Kamakaka et al. 1991; Laybourn and Kadonaga 1991). The soluble nuclear fraction from Drosophila embryos (Kamakaka et al. 1991) was used as the source of basal transcription factors. The soluble nuclear fraction was prepared by the method of Kamakaka et al. (1991), except that $0.1 \mathrm{M} \mathrm{KCl}$ was used instead of $0.4 \mathrm{M}$ potassium glutamate in the nuclear extraction buffer to yield a soluble nuclear fraction of $8 \mathrm{mg} / \mathrm{ml}$ of total protein concentration. In experiments involving transcription of chromatin reconstituted from double-stranded DNA, the
DNA template was $\mathrm{pG}_{5} \mathrm{E} 4 \mathrm{Kr}$. This plasmid $(9.8 \mathrm{kbp})$ was constructed by insertion of a $6.5-\mathrm{kbp} \mathrm{BamHI-EcoRI} \mathrm{fragment} \mathrm{(with}$ an EcoRI linker flanking the BamHI site) from $\lambda E R 3$, which contains the Drosophila Krüppel gene (Preiss et al. 1985), into the unique EcoRI site located downstream of the adenovirus E4 sequences in $\mathrm{pG}_{5} \mathrm{E} 4 \mathrm{~T}$ ( $\mathrm{Lin}$ et al. 1988). Studies involving transcription of chromatin that was prepared by DNA replication and chromatin assembly were carried out with $\mathrm{M}_{13} \mathrm{G}_{5} \mathrm{E} 4$ singlestranded DNA, which is described above. It is also relevant to note that incubation of either the H1-containing or the H1deficient reconstituted chromatin in the same buffer used in transcription reactions does not cause significant $(<15 \%$ ) aggregation/precipitation of the chromatin.

In a typical experiment, chromatin was reconstituted in the presence or absence of Gal4-VP16, purified by sucrose gradient sedimentation, and dialyzed overnight against $12.5 \mathrm{mM}$ HEPES $\left(\mathrm{K}^{+}\right), 0.1 \mathrm{~mm}$ EDTA, and $50 \mathrm{~mm} \mathrm{KCl}$. Chromatin containing 50 ng of DNA / the amount of DNA was estimated by deproteinization of the chromatin and agarose gel electrophoresis/ethidium bromide staining with DNA concentration standards) was transcribed with $10 \mu \mathrm{l}(80 \mu \mathrm{g}$ total protein) of the soluble nuclear fraction from Drosophila embryos as follows. First, in samples to which Gal4-VP16 was added to the chromatin after reconstitution, the chromatin was preincubated with additional Gal4-VP16 protein (at an amount of 10 Gal4-VP16 dimers per Gal4-binding site) at $25^{\circ} \mathrm{C}$ for $15 \mathrm{~min}$. Then, the chromatin, Gal4-VP16 (when included in the reaction) and soluble nuclear fraction $(10 \mu \mathrm{l} ; \sim 80 \mu \mathrm{g})$ were incubated at $25^{\circ} \mathrm{C}$ for $30 \mathrm{~min}$ to allow assembly of preinitiation complexes. Ribonucleoside $5^{\prime}$ triphosphates were then added to initiate transcription, and the reactions were carried out for $30 \mathrm{~min}$ at $25^{\circ} \mathrm{C}$. The resulting transcripts were subjected to primer extension analysis with the AdE4 primer (Kerrigan et al. 1991). Quantitation of the reverse transcription products was performed by using a Molecular Dynamics PhosphorImager with ImageQuant software. All experiments were performed a minimum of two times to ensure reproducibility of the data.

It is also important to note that we did not observe complete derepression of chromatin-mediated inhibition of transcription by Gal4-VP16, that is, we could not attain levels of transcription with chromatin templates comparable with those with naked DNA templates (see Figs. 4 and 7). There are a few possible explanations for this effect: (1) Gal4-VP16 alone may not be able to counteract fully the chromatin-mediated repression of transcription initiation; (2) both initiation and elongation of transcription may be repressed on packaging into chromatin, and in the presence of Gal4-VP16, the remaining repression of transcription may be the result of inhibition of elongation (see, e.g., Izban and Luse 1991); and (3) a large fraction of the templates may be irreversibly inactivated with chromatin reconstitution. The use of a promoter-directed transcription assay necessarily entails carrying out both initiation and elongation of transcription. In the future, the use of assays that specifically focus on transcription elongation may clarify the effects of chromatin reconstituted with the Drosophila S-190 extract on elongation.

\section{Acknowledgments}

We thank P. Becker, C. Wu, A. Wolffe, and J. Newport for many helpful suggestions regarding reconstitution of chromatin. We also thank J. Langmore, R. Paretti, G. Tank, B. Hamkalo, L. Washington, and $\mathrm{K}$. Tokuyasu for generous help and guidance with the electron microscopy of the chromatin. We are grateful to B. Zimm, C. George, M. Pazin, C. Tyree, S. Paranjape, and G. 
Croston for critical reading of the manuscript. J. T. K. is a Lucille P. Markey Scholar in the Biomedical Sciences and a Presidential Faculty Fellow. This work was supported by grants from the National Institutes of Health, the National Science Foundation, the Council for Tobacco Research, and the Lucille P. Markey Charitable Trust.

The publication costs of this article were defrayed in part by payment of page charges. This article must therefore be hereby marked "advertisement" in accordance with 18 USC section 1734 solely to indicate this fact.

\section{References}

Adams, C.C. and J.L. Workman. 1993. Nucleosome displacement in transcription. Cell 72: 1-20.

Allan, J., P.G. Hartman, C. Crane-Robinson, and F.X. Aviles. 1980. The structure of histone $\mathrm{H} 1$ and its location in chromatin. Nature 288: 675-679.

Almouzni, G. and M. Méchali. 1988. Assembly of spaced chromatin promoted by DNA synthesis in extracts from Xenopus eggs. EMBO $J$. 7: 665-672.

Almouzni, G., M. Méchali, and A.P. Wolffe. 1990. Competition between transcription complex assembly and chromatin assembly on replicating DNA. EMBO J. 9: 573-582.

Archer, T.K., M.G. Cordingley, R.G. Wolford, and G.L. Hager. 1991. Transcription factor access is mediated by accurately positioned nucleosomes on the mouse mammary tumor virus promoter. Mol. Cell. Biol. 11: 688-698.

Bates, D.L. and J.O. Thomas. 1981. Histones Hl and H5: One or two molecules per nucleosome? Nucleic Acids Res. 9: 58835894.

Becker, P.B. and C. Wu. 1992. Cell-free system for assembly of transcriptionally repressed chromatin from Drosophila embryos. Mol. Cell. Biol. 12: 2241-2249.

Berrios, M. and A.A. Avilion. 1990. Nuclear formation in a Drosophila cell-free system. Exp. Cell Res. 191: 64-70.

Bresnick, E.H., M. Bustin, V. Marsaud, H. Richard-Foy, and G.L. Hager. 1992. The transcriptionally-active MMTV promoter is depleted of histone Hl. Nucleic Acids Res. 20: 273-278.

Brown, D.D. 1984. The role of stable complexes that repress and activate eucaryotic genes. Cell 37: 359-365.

Butler, P.J.G. and J.O. Thomas. 1980. Changes in chromatin folding in solution. I. Mol. Biol. 140: 505-529.

Chasman, D.I., J. Leatherwood, M. Carey, M. Ptashne, and R.D. Kornberg. 1989. Activation of yeast polymerase II transcription by herpes VP16 and Gal4 derivatives in vitro. Mol. Cell. Biol. 9: 4746-4749.

Conaway, J.W. and R.C. Conaway. 1991. Initiation of eukaryotic messenger RNA synthesis. I. Biol. Chem. 266: 1772117724.

Crevel, G. and S. Cotterill. 1991. DNA replication in cell-free extracts from Drosophila melanogaster. EMBO I. 10: 43614369.

Croston, G.E. and J.T. Kadonaga. 1993. Role of chromatin structure in the regulation of transcription by RNA polymerase II. Curr. Opin. Cell Biol. 5: 417-423.

Croston, G.E., L.A. Kerrigan, L. Lira, D.R. Marshak, and J.T. Kadonaga. 1991a. Sequence-specific antirepression of histone Hl-mediated inhibition of basal RNA polymerase II transcription. Science 251: 643-649.

Croston, G.E., L.M. Lira, and J.T. Kadonaga. 1991b. A general method for the purification of $\mathrm{Hl}$ histones that are active for repression of basal RNA polymerase II transcription. Protein Expression Purification 2: 162-169.

Croston, G.E., P.J. Laybourn, S.M. Paranjape, and J.T. Kadonaga.
1992. Mechanism of transcriptional antirepression by Gal4 VP16. Genes \& Dev. 6: 2270-2281.

Drapkin, R., A. Merino, and D. Reinberg. 1993. Regulation of RNA polymerase II transcription. Curr. Opin. Cell Biol. 5: $469-476$.

Felsenfeld, G. 1992. Chromatin as an essential part of the transcriptional mechanism. Nature 355: 219-224.

Germond, J.E., B. Hirt, P. Oudet, M. Gross-Bellard, and P. Chambon. 1975. Folding of the DNA double helix in chromatin-like structures from simian virus 40 . Proc. Natl. Acad. Sci. 72: 1843-1847.

Glikin, G.C., I. Ruberti, and A. Worcel. 1984. Chromatin assembly in Xenopus oocytes: In vitro studies. Cell 37: 33-41.

Gralla, J. D. 1985. Rapid "footprinting" on supercoiled DNA. Proc. Nat1. Acad. Sci. 82:3078-3081.

Grunstein, M. 1990. Histone function in transcription. Annu. Rev. Cell Biol. 6: 643-678.

Hahn, S. 1993. Structure (?) and function of acidic transcription activators. Cell 72: 481-483.

Izban, M.G. and D.S. Luse. 1991. Transcription on nucleosomal templates by RNA polymerase II in vitro: Inhibition of elongation with enhancement of sequence-specific pausing. Genes \& Dev. 5: 683-696.

Johnson, P.F. and S.L. McKnight. 1989. Eukaryotic transcriptional regulatory proteins. Annu. Rev. Biochem. 58: 799839.

Kadonaga, J.T. 1990. Assembly and disassembly of the Drosophila RNA polymerase II complex during transcription. $J$. Biol. Chem. 265: 2624-2631.

Kamakaka, R.T. and J.O. Thomas. 1990. Chromatin structure of transcriptionally competent and repressed genes. EMBO $J$. 9: 3997-4006.

Kamakaka, R.T., C.M. Tyree, and J.T. Kadonaga. 1991. Accurate and efficient RNA polymerase II transcription with a soluble nuclear fraction derived from Drosophila embryos. Proc. Natl. Acad. Sci. 88: 1024-1028.

Keller, W. 1975. Determination of the number of superhelical turns in simian virus 40 DNA by gel electrophoresis. Proc. Natl. Acad. Sci. 72: 4876-4880.

Kerrigan, L.A., G.E. Croston, L.M. Lira, and J.T. Kadonaga. 1991. Sequence-specific transcriptional antirepression of the Drosophila Krüppel gene by the GAGA factor. I. Biol. Chem. 266: 574-582.

Kornberg, R.D. and Y. Lorch. 1991. Irresistible force meets immovable object: Transcription and the nucleosome. Cell 67: 833-836.

Laybourn, P.J. and J.T. Kadonaga. 1991. Role of nucleosomal cores and histone $\mathrm{Hl}$ in regulation of transcription by RNA polymerase II. Science 254: 238-245.

- 1992. Threshold phenomena and long-distance activation of transcription by RNA polymerase II. Science 257: 1682-1685.

Lin, Y.-S., M.F. Carey, M. Ptashne, and M.R. Green. 1988. Gal4 derivatives function alone and synergistically with mammalian activators in vitro. Cell 54: 659-664.

Lorch, Y., J.W. LaPointe, and R.D. Kornberg. 1992. Initiation on chromatin templates in a yeast RNA polymerase II transcription system. Genes \& Dev. 6: 2282-2287.

Majumder, S., M. Miranda, and M.L. DePamphilis. 1993. Analysis of gene expression in mouse preimplantation embryos demonstrates that the primary role of enhancers is to relieve repression of promoters. EMBO I. 12: 1131-1140.

Mitchell, P.J. and R. Tjian. 1989. Transcriptional regulation in mammalian cells by sequence-specific DNA binding proteins. Science 245: 371-378.

Nacheva, B.A., D.Y. Guschin, O.V. Preobrazhenskaya, V.L. Kar- 
pov, K.K. Ebralidse, and A.D. Mirzabekov. 1989. Change in the pattern of histone binding to DNA upon transcriptional activation. Cell 58: 27-36.

Nelson, P.P., S.C. Albright, J.M. Wiseman, and W.T. Garrard. 1979. Reassociation of histone $\mathrm{Hl}$ with nucleosomes. J. Biol. Chem. 254: 11751-11760.

Newport, J. 1987. Nuclear reconstitution in vitro: Stages of assembly around protein-free DNA. Cell 48: 205-217.

Noll, M. and R.D. Kornberg. 1977. Action of micrococcal nuclease on chromatin and the location of histone H1. J. Mol. Biol. 109: 393-404.

Peck, L.J. and J.C. Wang. 1983. Energetics of B-to-Z transition in DNA. Proc. Natl. Acad. Sci. 80: 6206-6210.

Perlmann, T. and Ö. Wrange. 1988. Specific glucocorticoid receptor binding to DNA reconstituted in a nucleosome. EMBO I. 7: 3073-3079.

Piña, B., U. Brüggemeier, and M. Beato. 1990. Nucleosome positioning modulates accessibility of regulatory proteins to the mouse mammary tumor virus promoter. Cell 60: 719731.

Postnikov, Y.V., V.V. Shick, A.V. Belyavsky, K.R. Khrapko, K.L. Brodolin, T.A. Nikolskaya, and A.D. Mirzabekov. 1991. Distribution of high mobility group proteins $1 / 2, \mathrm{E}$ and $14 / 17$ and linker histones $\mathrm{H} 1$ and $\mathrm{H} 5$ on transcribed and non-transcribed regions of chicken erythrocyte chromatin. Nucleic Acids Res. 19: 717-725.

Preiss, A., U.B. Rosenberg, A. Kienlin, E. Seifert, and H. Jäckle. 1985. Molecular genetics of Krüppel, a gene required for segmentation of the Drosophila embryo. Nature 313: 27-32.

Ptashne, M. 1988. How eukaryotic transcriptional activators work. Nature 335: 683-689.

Pugh, B.F. and R. Tjian. 1992. Diverse transcriptional functions of the multisubunit eukaryotic TFIID complex. $J$. Biol. Chem. 267: 679-682.

Richard-Foy, H. and G.L. Hager. 1987. Sequence-specific positioning of nucleosomes over the steroid-inducible MMTV promoter. $E M B O$ /. 6: 2321-2328.

Rodríguez-Campos, A., A. Shimamura, and A. Worcel. 1989. Assembly and properties of chromatin containing histone H1. J. Mol. Biol. 209: 135-150.

Roeder, R.G. 1991. The complexities of eukaryotic transcription initiation: Regulation of preinitiation complex assembly. Trends Biochem. Sci. 16: 402-408.

Rougvie, A.E. and J.T. Lis. 1988. The RNA polymerase II molecule at the $5^{\prime}$ end of the uninduced $h s p 70$ gene of $D$. melanogaster is transcriptionally engaged. Cell 54: 795-804.

Sadowski, I., J. Ma, S. Triezenberg, and M. Ptashne. 1988. Gal4VP16 is an unusually potent transcriptional activator. $\mathrm{Na}$ ture 335: 563-564.

Sakaguchi, K. and J.B. Boyd. 1985. Purification and characterization of a DNA polymerase $\beta$ from Drosophila. J. Biol. Chem. 260: 10406-10411.

Saltzman, A.G. and R. Weinmann. 1989. Promoter specificity and modulation of RNA polymerase II transcription. FASEB I. 3: 1723-1733.

Sawadogo, M. and A. Sentenac. 1990. RNA polymerase B (II) and general transcription factors. Annu. Rev. Biochem. 59: 711754.

Schild, C., F.-X. Claret, W. Wahli, and A.P. Wolffe. 1993. A nucleosome-dependent static loop potentiates estrogen-regulated transcription from the Xenopus vitellogenin Bl promoter in vitro. $E M B O J$. 12: 423-433.

Schlissel, M.S. and D.D. Brown. 1984. The transcriptional regulation of Xenopus 5S RNA genes in chromatin: The roles of active stable transcription complexes and histone $\mathrm{Hl}$. Cell 37: 903-913.
Schmid, A., K.-D. Fascher, and W. Hörz. 1992. Nucleosome disruption at the yeast PHO5 promoter upon PHO5 induction occurs in the absence of DNA replication. Cell 71: 853-864.

Shimamura, A. and A. Worcel. 1989. The assembly of regularly spaced nucleosomes in the Xenopus oocyte S-150 extract is accompanied by deacetylation of histone H4. J. Biol. Chem. 264: 14524-14530.

Shimamura, A., D. Tremethick, and A. Worcel. 1988. Characterization of the repressed 5S DNA minichromosomes assembled in vitro with a high-speed supernatant of Xenopus laevis oocytes. Mol. Cell. Biol. 8: 4257-4269.

Shimamura, A., M. Sapp, A. Rodríguez-Campos, and A. Worcel. 1989a. Histone Hl represses transcription from minichromosomes assembled in vitro. Mol. Cell. Biol. 9: 5573-5584.

Shimamura, A., B. Jessee, and A. Worcel. 1989b. Assembly of chromatin with oocyte extracts. Methods Enzymol. 170: 603-612.

Simpson, R.T. 1978. Structure of the chromatosome, a chromatin particle containing 160 base pairs of DNA and all the histones. Biochemistry 17: 5524-5531.

- 1991. Nucleosome positioning: Occurrence, mechanisms, and functional consequences. Prog. Nucleic Acid Res. Mol. Biol. 40: 143-184.

Simpson, R.T., F. Thoma, and J.M. Brubaker. 1985. Chromatin reconstituted from tandemly repeated cloned DNA fragments and core histones: A model system for study of higher order structure. Cell 42: 799-808.

Solomon, M.J. and A. Varshavsky. 1987. A nuclease-hypersensitive region forms de novo after chromosome replication. Mol. Cell. Biol. 7: 3822-3825.

Stein, A. 1989 . Reconstitution of chromatin from purified components. Methods Enzymol. 170: 585-603.

Svaren, J. and R. Chalkley. 1990. The structure and assembly of active chromatin. Trends Genet. 6: 52-56.

Taylor, I.C.A., J.L. Workman, T.J. Schuetz, and R.E. Kingston. 1991. Facilitated binding of Gal4 and heat shock factor to nucleosomal templates: Differential function of DNA-binding domains. Genes \& Dev. 5: 1285-1298.

Thoma, F., T. Koller, and A. Klug. 1979. Involvement of histone $\mathrm{Hl}$ in the organization of the nucleosome and of the salt dependent superstructures of chromatin. $J$. Cell Biol. 83: 403-427.

Thomas, J.O. and R.D. Kornberg. 1978. The study of histonehistone associations by chemical cross-linking. Methods Cell Biol. 18: 429-440.

Ulitzur, N. and Y. Gruenbaum. 1989. Nuclear envelope assembly around sperm chromatin in cell-free preparations from Drosophila embryos. FEBS Lett. 259: 113-116.

van Holde, K.E. 1989. Chromatin Springer-Verlag, New York.

Varshavsky, A.J., V.V. Bakayev, and G.P. Georgiev. 1976. Heterogeneity of chromatin subunits in vitro and location of histone Hl. Nucleic Acids Res. 3: 477-492.

Wampler, S.L., C.M. Tyree, and J.T. Kadonaga. 1990. Fractionation of the general RNA polymerase II transcription factors from Drosophila embryos. J. Biol. Chem. 265: 21223-21231.

Weintraub, H. 1979. Assembly of an active chromatin structure during replication. Nucleic Acids Res. 7: 781-792.

. 1985. Assembly and propagation of repressed and derepressed chromosomal states. Cell 42: 705-711.

Weis, L. and D. Reinberg. 1992. Transcription by RNA polymerase II: Initiator-directed formation of transcription-competent complexes. FASEB J. 6: 3300-3309.

Wolffe, A.P. 1989. Dominant and specific repression of Xenopus oocyte 5S RNA genes and satellite I DNA by histone $\mathrm{Hl}$. EMBO I. 8: 527-537.

- 1992. Chromatin: Structure and Function. Academic 
Press, San Diego, CA.

Workman, J.L. and A.R. Buchman. 1993. Multiple functions of nucleosomes and regulatory factors in transcription. Trends Biochem. Sci. 18: 90-95.

Workman, J.L. and R.E. Kingston. 1992. Nucleosome core displacement in vitro via a metastable transcription factor-nucleosome complex. Science 258: 1780-1784.

Workman, J.L., I.C.A. Taylor, and R.E. Kingston. 1991. Activation domains of stably bound Gal4 derivatives alleviate repression of promoters by nucleosomes. Cell 64: 533-544.

Zawel, L. and D. Reinberg. 1992. Advances in RNA polymerase II transcription. Curr. Opin. Cell Biol. 4: 488-495.

1993. Initiation of transcription by RNA polymerase II: A multi-step process. Prog. Nucleic Acid Res. Mol. Biol. 44: $67-108$. 


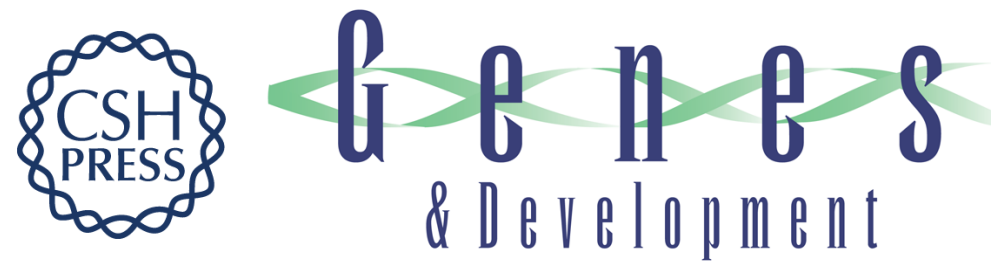

\section{Potentiation of RNA polymerase II transcription by Gal4-VP16 during but not after DNA replication and chromatin assembly.}

R T Kamakaka, M Bulger and J T Kadonaga

Genes Dev. 1993, 7:

Access the most recent version at doi:10.1101/gad.7.9.1779

References This article cites 86 articles, 29 of which can be accessed free at:

http://genesdev.cshlp.org/content/7/9/1779.full.html\#ref-list-1

License

Email Alerting

Service

Receive free email alerts when new articles cite this article - sign up in the box at the top right corner of the article or click here.

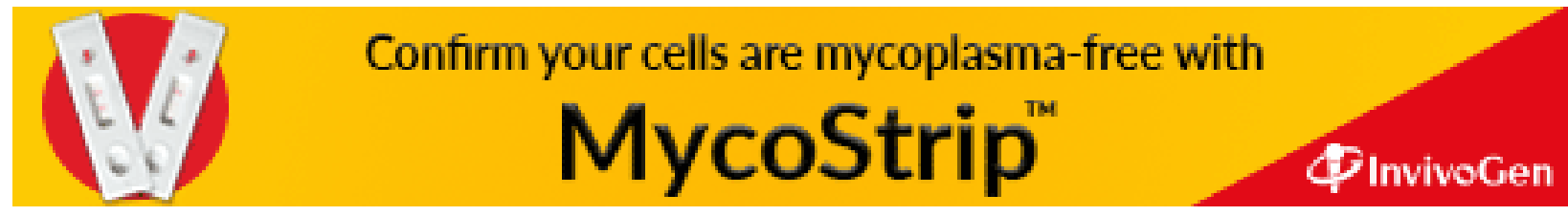

